\title{
Seagrass collapse due to synergistic stressors is not anticipated by phenological changes
}

Giulia Ceccherelli ${ }^{*}$, Silvia Oliva ${ }^{1}$, Stefania Pinna ${ }^{1}$, Luigi Piazzi ${ }^{1}$, Gabriele Procaccini², Lazaro Marin-Guirao ${ }^{2}$, Emanuela Dattolo ${ }^{2}$, Roberto Gallia ${ }^{2}$, Gabriella La Manna ${ }^{1,3}$, Paola

Gennaro ${ }^{4}$, Monya M. Costa ${ }^{5}$, Isabel Barrote ${ }^{5}$, João Silva ${ }^{5}$, Fabio Bulleri ${ }^{6}$

${ }^{1}$ Dipartimento di Scienze della Natura e del Territorio, Polo Bionaturalistico, University of Sassari, via Piandanna 4, 07100 Sassari, Italy

2Stazione Zoologica Anton Dohrn, Villa Comunale, Napoli, Italy

${ }^{3}$ MareTerra - Environmental Research and Conservation, Regione Sa Londra 9, Alghero (SS), Italy

${ }^{4}$ Italian National Institute for Environmental Protection and Research (ISPRA), via di Castel Romano 100, Roma, Italy

${ }^{5}$ CCMAR - Centre of Marine Sciences, University of Algarve, Faro, Portugal

${ }^{6}$ Department of Biology, University of Pisa, via Derna 1, Pisa

\section{*corresponding author}

GIULIA CECCHERELLI

Dipartimento di Scienze della Natura e del Territorio,

Polo Bionaturalistico,

University of Sassari,

via Piandanna 4, 07100 Sassari, Italy

phone: $+39-079-228643$

ha formattato: Inglese (Australia)

Author contributions: GC, SO, and LP conceived and designed the experiments. GC, SO, SP and LP performed the experiments. GP, LMG, ED, RG, PG, MMC, IB, JS analysed the sampled material, FB analysed the data. GC and FB led the writing of the ms. All authors contributed critically to the drafts and gave final approval for publication.

running title: Synergistic stressors cause seagrass collapse 
Seagrasses are globally declining and often their loss is due to synergies among stressors. We investigated the interactive effects of eutrophication and burial on the Mediterranean seagrass, Posidonia oceanica. A field experiment was conducted to estimate whether shoot survival depends on the interactive effects of three levels of intensity of both stressors and to identify early changes in plants (i.e. morphological, physiological and biochemical, and expression of stress-related genes) that may serve to detect signals of imminent shoot density collapse. Sediment burial and nutrient enrichment produced interactive effects on $P$. oceanica shoot survival, as high nutrient levels had the potential to accelerate the regression of the seagrass exposed to high burial (HB). After 11 weeks, HB in combination with either high or medium nutrient enrichment, caused a shoot loss of about $60 \%$. Changes in morphology were poor predictors of the seagrass decline. Likewise, few biochemical variables were associated with $P$. oceanica survival (the phenolics, ORAC and leaf $\delta^{34} \mathrm{~S}$ ). By contrast, the expression of target genes had the highest correlation with plant survival: photosynthetic genes (ATPa, psbD and psbA) were upregulated in response to high burial, while carbon metabolism genes (CA-chl, PGK and GADPH) were down-regulated. Therefore, die-offs due to high sedimentation rate in eutrophic areas can only be anticipated by altered expression of stress-related genes that may warn the imminent seagrass collapse.

Management of local stressors, such as nutrient pollution, may enhance seagrass resilience in the face of the intensification of extreme climate events, such as floods. 


\section{Introduction}

Transitions between natural systems with radically different properties can occur abruptly. Important examples can be found in ecology (e.g., lake eutrophication and coral reef collapses), where regime shifts have consequences that are often irreversible (Bellwood et al. 2004, Carpenter 2011, Perry and Morgan 2017). Predicting and anticipating catastrophic regime shifts represents a timely objective to improve our ability to preserve biodiversity and ecosystem functioning in the face of escalating anthropogenic pressures (Boettiger and Hastings 2013). Among all systems, the coastal marine are experiencing a wide range of human-induced alterations, the magnitude of which increases with the local density of human populations. Generally, the various environmental stressors do not act in isolation (Crain et al. 2008); rather, the effects of individual stressors interact to generate cumulative impacts that can be greater or smaller than the sum of their individual impacts (i.e. synergistic or antagonistic effects). Nevertheless, predicting the effects of combinations of stressors is particularly challenging because mechanisms underpinning impact are rarely elucidated and either threshold or nonlinear responses to stressors remain unknown (Griffen et al. 2016).

The effects of multiple stressors on slow-growing, habitat-forming species, such as certain seagrasses, are particularly threatening. Seagrass meadows are among the most important and productive coastal systems (Costanza et al. 1997). They provide key ecological services, including nursery grounds, habitat (for a review see Heck et al., 2003), organic carbon production and export, nutrient cycling, sediment stabilization, trophic transfer to adjacent habitats (Hemminga and Duarte 2000, Larkum et al. 2006) and coastal protection from erosion (Fonseca and Cahalan 1992, Fonseca and Koehl 2006). Nonetheless, they are threatened by the rapid environmental changes caused by the expansion of coastal human populations. Rapid, large-scale seagrass loss over relatively 
short temporal scales has been reported throughout the world (Bulthuis 1983, Orth and Moore 1983, Fourqurean and Robblee 1999, Marbà et al. 2005, Walker et al. 2006). Stressors, such as sediments and nutrients inputs from terrestrial runoff, physical disturbance (e.g. trawling, anchoring), invasive species, disease, aquaculture, overgrazing, algal blooms and global warming, have been shown to cause seagrass declines at scales ranging from square meters to hundreds of square kilometres (e.g. Munkes 2005, Orth et al. 2006, Williams, 2007, Waycott et al. 2009, Bockelmann et al. 2011, Giakoumi et al. 2015). Overall, enhanced nutrients loading and sedimentation rates are likely the most common and significant causes of seagrass decline (Unsworth et al. 2015). Indeed, the current expansion of fish farming and other aquaculture practices (e.g., shellfish culture) can have serious consequences on local populations of seagrasses through increased deposition of organic matter and nutrients (Marbà et al. 2006). While eutrophication is considered as the main cause of seagrass loss at a regional scale, burial of plants due to anthropogenic-increased sedimentation or natural extreme events like storms or floods, has been identified as an important cause for local die-offs (Short and Wyllie-Echeverria 1996, Erftemeijer and Lewis 2006, Orth et al. 2006, Cabaço et al. 2008, Cabaço and Santos 2014).

Posidonia oceanica (L.) Delile is a slow-growing seagrass, endemic in the Mediterranean and experiencing a widespread decline throughout the basin (Telesca et al. 2015). The regression of $P$. oceanica beds and the consequent expansion of alternative habitats (e.g. algal turfs or dead seagrass rhizomes, generally referred to as "dead matte") is particularly common in the proximity of urban areas (Montefalcone et al. 2009, Tamburello et al. 2012). In addition to enhanced nutrient loading, $P$. oceanica meadows are exposed to increased sedimentation rates as a consequence of beach nourishment, dredging of waterways, shoreline armouring and severe climatic events (i.e. storms and floods). Correlative and experimental studies have assessed the effects of both 
eutrophication (Alcoverro et al. 1997, Delgado et al. 1999, Ruiz et al. 2001, Holmer et al. 2008) and burial on P. oceanica (Manzanera et al. 2011, Gera et al. 2014), but how organic load levels change the effects of burial is yet to be explored. Within this context, the identification of early warning signals for drastic declines would be a valuable tool for the management of seagrass meadows (McMahon et al. 2013, Macreadie et al. 2014, Roca et al. 2016). This goal has been pursued for pressing disturbances through correlative approaches (e.g., van Katwijk et al. 2011) that do not, however, allow estimating signs of imminent collapses.

Here, we investigate the interactive effects of eutrophication and burial on $P$. oceanica. A field experiment was conducted 1) to estimate whether shoot survival depends on the interactive effects of three levels of intensity of both stressors, using a full factorial design, and 2) to identify early changes in plant attributes (i.e. morphological/growth, physiological/biochemical, and expression of stress-related genes) that may serve as signals of imminent shoot density collapse (early warnings of degradation). In general, response time and sensitivity to stressors vary with the type of variable examined; thus, understanding how sensitivity to stressors may change according to the level of biological organization is essential to rationalise the choice of indicators of impending seagrass decline and to design monitoring programmes (Roca et al. 2016). Indicator specificity is expected to increase when moving towards lower levels of biological organisation (sensu, Whitham et al. 2006), from the structural metrics to specific physiological and molecular indicators (Adams and Greeley, 2000). Whether this general rule holds for $P$. oceanica remains utterly unexplored.

\section{Materials and Methods}

\subsection{Study site}


The study was carried out in a shallow (5-8 m deep) continuous $P$. oceanica meadow, on the north-west coast of Sardinia $\left(40^{\circ} 34.1 \mathrm{~N}, 09^{\circ} 8.5 \mathrm{E}\right)$. At this site, $P$. oceanica canopy structure in the inner meadow is well preserved (shoot density mean \pm SE $=699.4 \pm 38.6 \mathrm{~m}^{-2}, n=28$; canopy height mean $\left.\pm \mathrm{SE}=63.92 \pm 1.94 \mathrm{~cm}, n=35\right)$. At the site, the grazing sea urchin, Paracentrotus lividus, is present at low densities, whilst juveniles of the herbivore fish, Sarpa salpa, are common (GC, personal observations).

\subsection{Experimental design and set up}

The experiment started on the 29th of April 2015 and lasted until $P$. oceanica shoot mortality exceeded $60 \%$ in some treatments (i.e. 11 weeks, see Results). The hypotheses were tested by running a fully-factorial experiment of sediment burial (high, medium and control) and nutrient enhancement (high, medium and ambient) treatments. Twenty-seven circular patches (hereafter referred to as experimental units) were randomly selected across the seagrass meadow, at least $3 \mathrm{~m}$ apart one from another. Within each unit, a PVC cylinder (40 cm in height and diameter) was inserted about $10 \mathrm{~cm}$ deep into the bottom, thus leaving about $30 \mathrm{~cm}$ of the cylinder above the sediment (Fig. S1). Each cylinder enclosed between 81 and 109 P. oceanica shoots.

High, medium and control burial ( $\mathrm{HB}, \mathrm{MB}$ and $\mathrm{CB}$ ) were obtained by adding $12.5 \mathrm{~L}$, $5.0 \mathrm{~L}$ and $0 \mathrm{~L}$ of sediment (corresponding to a layer $10 \mathrm{~cm}, 4 \mathrm{~cm}$ and $0 \mathrm{~cm}$ tick), respectively accordingly with Manzanera et al. (2011). We used washed sand for playgrounds in our experiment, as this sand is similar in grain size (coarse sand, 0-1 mm) and mineralogy (carbonate) to sediment at the study site. This ensured that all experimental units were treated with the sand characterized by the same granulometry, devoid of fauna and low in organic content. Depending on the treatment, $P$. oceanica plants were buried with $4 \mathrm{~cm}$ of sediment over the ligula in $\mathrm{HB}$, at the ligula height in $\mathrm{MB}$, 
and unburied in CB. When scuba divers filled experimental units with sand, care was taken not to damage the leaves and to keep the plants upright during the process.

Also, high, medium and ambient nutrients ( $\mathrm{HN}, \mathrm{MN}$ and $\mathrm{AN})$ were obtained by adding $80 \mathrm{~g}, 40 \mathrm{~g}$ and $0 \mathrm{~g}$ of homogenized fish fodder (protein $56.66 \%$, fat $24.88 \%$, cellulose $5.53 \%$, ash $9.4 \%$, phosphorous $1.35 \%$, calcium $1.73 \%$ and sodium $0.46 \%$ ) to the sediment in each unit. Treatment levels were decided on the basis of nutrient release from offshore fish farms (Garcia-Sanz et al. 2010). Fish fodder was used to simulate effects of eutrophication related to land and coastal use change (from deforestation to aquaculture), which often increases the organic matter and nutrients input into coastal sediments. The use of fish fodder not only increases ammonium levels through mineralization, but also fuels the production of sulfide (Burkholder et al. 2007). Sulfide is a strongly phytotoxic compound, as it blocks the activity of cytochrome oxidase and other metal containing enzymes, which may lead to massive seagrass die-offs (Govers et al. 2014).

Each unit was randomly assigned to one of the six combinations of treatments $(n=3)$. Three extra cylinders with large holes and not exposed to either sediment or fish fodder addition were used as procedural controls. The outer edge of all units was not parted off and a trans-cylinder clonal integration between shoots was not impeded with the aim not to impose further stress on shoots. The effects of the experimental conditions on shoot survival were evaluated every few weeks (see section 2.3.2) with the aim of catching the shoot mortality of about $20 \%$ and $60 \%$ in the harshest treatments that had corresponded to week 3 and 11 . Then, to identify indicators of mortality, shoot survival at week 11 was related with morphological, physiological/biochemical variables and expression of stressrelated genes, estimated at week 3 .

\subsection{Data collection and analyses}




\subsubsection{Assessment of trophic enrichment}

In order to estimate concentrations of inorganic nutrients, samples were taken from the water column at two dates chosen at random during the experiment (week 7 and 11). At each date, two replicate water samples were taken in each unit using a $125-\mathrm{mL}$ sterile bottle about $5 \mathrm{~cm}$ above $P$. oceanica rhizomes. Samples were shaken and then filtered $(0.45 \mu \mathrm{m}$ mesh size $)$ as soon as they were brought to the surface. Samples were frozen in liquid nitrogen for transportation to the laboratory, where concentrations of ammonia, nitrate, nitrite and ortophosphate were determined using a continuous-flow AA3 AutoAnalyzer (Bran-Luebbe) and expressed in $\mu \mathrm{mol} \mathrm{I-1}$. Concentrations of dissolved inorganic nitrogen (DIN, ammonia+nitrate+nitrite) and phosphorus (DIP as $\mathrm{P}-\mathrm{PO}_{4}{ }^{3-}$ ) were analysed by means of two one-way analyses of variance (ANOVA) testing the effect of Nutrient enrichment ( 3 levels, $\mathrm{HN}, \mathrm{MN}$ and $\mathrm{AN}$ ) on the pooled data taken in each unit ( $n=18)$. Cochran's C-test was used before each analysis to check for homogeneity of variance, and data were transformed when necessary. SNK test was used for a posteriori means comparisons (Underwood 1997).

\subsection{2. $P$. oceanica survival}

P. oceanica shoot density was counted at week $0,3,7,9$ and 11 to estimate shoot survival (assessed as the percentage of shoots with leaves) through time. Shoot survival (\%) after 3 and 11 weeks was analysed by means of two 2-way analyses of variance (ANOVA), including the factors Burial (3 levels, $\mathrm{HB}, \mathrm{MB}$ and $\mathrm{CB}$, fixed) and Nutrient addition (3 levels, $\mathrm{HN}, \mathrm{MN}$ and $\mathrm{AN}$ ) both fixed and orthogonal $(n=3)$. Cochran's C-test was used before each analysis to check for homogeneity of variance and data were transformed when necessary (Underwood 1997). 
To evaluate the effects of procedural controls (PC), $P$. oceanica shoot survival at week 3 and 11 was also analysed by two one-way ANOVAs (PC vs. CBAN, $n=3$ ). Cochran's C-test and SNK test were run as explained above.

\subsubsection{P. oceanica morphological/growth and physiological/biochemical variables}

Six morphological variables (epiphyte load, \% of leaves with necrosis, maximum leaf length, mean leaf length, number of leaves, shoot biomass), leaf growth rate, and eleven physiological/biochemical variables (leaf N, C and S content and corresponding isotopic signature $\delta^{15} \mathrm{~N}, \delta^{13} \mathrm{C}, \delta^{34} \mathrm{~S}$, the antioxidant capacity through the oxygen radical absorbance capacity, ORAC, Trolox equivalent antioxidant capacity, TEAC and phenolics) (Table 1) were estimated after 3 weeks, when shoot mortality was still inconspicuous (see Results). Selection of these variables was based on the review made by Roca et al. (2016).

Among the morphological variables, epiphyte load was estimated as the weight of the epiphytes obtained from scraping the shoots with a razor blade (referred to the total weight of scraped leaves). The incidence of leaf necrosis was estimated as the percentage of leaves showing marks of necrosis (black areas or spots). Leaf growth rate was assessed using a modified leaf punching technique. At the beginning of the experiment, three shoots per unit were marked by punching a hole just above the leaf base-leaf blade junction of the outermost leaf with a hypodermic needle, and tagged with a plastic cable tie. After 20 days, the punched shoots were collected and the length of the newly produced tissue in each shoot measured.

Among the physiological/biochemical variables, ORAC, TEAC and phenolics were extracted in frozen leaf tissue samples as described in Costa et al. (2005) and estimated following Huang et al (2002), Re et al. (1999), and Folin-Ciocalteu method (Booker and Miller 1998, Migliore et al. 2007), respectively. Leaf N, C, and S (\%) were determined in 
samples of ca. $3.5 \mathrm{mg}$ of dried, finely ground and homogenized material from each unit. Leaf $\mathrm{N}, \mathrm{C}$ and $\mathrm{S}$ isotopic signature, was analysed through elemental analyser combustion for continuous flow isotope ratio mass spectroscopy.

Effects of Burial (3 levels, HB, MB and CB, fixed) and Nutrients (3 levels, HN, MN and AN) on morphological/growth and physiological/biochemical variables $(n=3)$ at week 3 were analysed by means of two 2-way analyses of variance (ANOVA). Cochran's C-test was used before each analysis to check for homogeneity of variance (Underwood 1997).

\subsection{4. $P$. oceanica expression of stress-related genes}

The expression of ten stress-related genes (GADPH, SHSP, HSP90, PGK, CAB-151, psbD, psbA, CA-chl, rbcl, and ATPa), (Table 1) were estimated after 3 weeks. At this aim three shoots for each experimental unit were collected after 3 weeks of treatment. A $4 \mathrm{~cm}$ leaf segment from the youngest fully mature leaves of each shoot (usually the second-rank leaf) was collected and rapidly cleaned from epiphytes with a razor blade, towel-dried and immediately stored in RNAlater® tissue collection solution (Ambion, Life Technologies). Samples were then transported to the laboratory, preserved one night at $4{ }^{\circ} \mathrm{C}$ and stored at $-20 \circ \mathrm{C}$ until RNA extraction.

After total RNA extraction (Mazzuca et al. 2013), RNA quantity and purity were assessed by Nanodrop (ND-1000 UV-Vis spectrophotometer; NanoDrop Technologies) and $1 \%$ agarose gel electrophoresis. Average Abs260/280 nm and Abs260/230 nm ratios (2.0 and 1.8, respectively) have indicated the absence of protein and solvent contaminations, while gel electrophoresis has showed intact RNA, with sharp ribosomal bands. Total RNA (500 ng) was reverse-transcribed in complementary DNA (cDNA) with the iScript ${ }^{\mathrm{TM}}$ cDNA Synthesis Kit (Bio-Rad) using the GeneAmp PCR System 9700 (Perkin Elmer). 
The target genes were selected on the basis of the two key events that mandatorily occur in the light and dark reactions of photosynthesis and can be hampered by biotic and abiotic stressful conditions, reducing plant productivity and survival (Ashraf and Harris, 2013). In light reactions, light energy is harvested by antenna pigments, channelled to photosystem II (PSII) to produce photochemistry and converted into chemical energy (i.e. ATP) and reducing power (i.e. NAPDH) by the flow of electrons along the electron transport chain. Particularly, we have selected and analyzed genes coding for a putative fundamental protein of the photosynthetic antenna complex (CAB-151): the two PSII core proteins D1 and D2 (psbA and psbD) and a putative chloroplastic ATP synthase subunit alpha (ATPa). In dark reactions, $\mathrm{CO}_{2}$ is fixed into carbohydrates in the Calvin-Benson cycle by using ATP and NADPH produced in the light reactions. In relation to this cycle, we have selected several putative genes encoding key enzymes of the plant carbon metabolism: the large subunit of the RuBisCO ( $\mathrm{rbcl}$ ), directly involved in $\mathrm{CO}_{2}$ fixation, and a chloroplast carbonic anhydrase (CA-chl) that catalyzes the conversion of $\mathrm{HCO}_{3}^{-}$into $\mathrm{CO}_{2}$. We also selected two major enzymes involved in glycolysis, glyceraldehyde-3phosphate dehydrogenase (GAPDH) and phosphoglycerate kinase (PGK), for obtaining energy and carbon molecules from glucose. Finally, two general stress genes were also included in the analysis as they are ubiquitous heat stress proteins in environmental stress: the molecular chaperone (HSP90) and one putative small heat shock protein (SHSP). All selected genes were already investigated in other studies (Table S1). Primers sequences and GenBank Accession Numbers are reported in the reference in which the genes have been selected for the first time. The expression stability of a set of three putative reference genes already tested in P. oceanica (i.e. EF1A, 18S and L23; Serra et al. 2012) was evaluated by running GeNorm (Vandesompele et al. 2002) and Normfinder (Andersen et al. 2004). According to stability analysis, two genes, namely 18 S and L23 (Fig. S2), were used to normalize gene expression data. 
After normalizing by each primer efficiency (all $>0.92 \%$ and $\mathrm{R}^{2}>0.96$ ), relative treatment gene expression values were calculated as the negative differences in cycles to cross the threshold value $(-\Delta \mathrm{CT})$ between the reference genes and the respective target genes $\left(-\Delta C T=C T_{\text {reference }}-C_{\text {target }}\right)$. Subsequently, fold expression changes were calculated for graphical purposes according to the equation: fold expression change $= \pm$ $2^{(\mid(-\Delta C \text { Ttreatment) })-(-\Delta C \text { C Tontrol }) \mid)}$

Effects of Burial (3 levels, HB, MB and CB, fixed) and Nutrients (3 levels, HN, MN and $\mathrm{AN}$ ) on the relative expression of target genes ( $-\Delta \mathrm{CT}$ values; $\mathrm{n}=3$ ) were analysed by means of 2-way analyses of variance (ANOVA). Cochran's C-test was used before each analysis to check for homogeneity of variance (Underwood 1997).

\subsubsection{Assessment of the predictive variables}

In order to identify predictors of shoot survival of $P$. oceanica under different combinations of burial and nutrients enhancement levels, separate multiple regressions were run between each of the four groups of response variables included in the study (morphological/growth, antioxidant, isotopes, and gene expression) and shoot survival. More specifically, values of explanatory variables measured at week 3 were used as predictors of shoot survival at week 11 . Collinearity among covariates was assessed by means of Variance Inflation Factor (VIF) procedures. Covariates with highest VIF values, calculated using the $\mathrm{R}$ car package, were sequentially dropped from the model, until all VIF values were smaller than 3, as recommended by Zuur et al. (2010). Linearity and homogeneity of variances was visually checked by means of residual plots. Log transformation of data was effective in enhancing homogeneity of variances. For each group of variables, the best-fit model was selected by means of a stepwise procedure (both directions) using the stepAIC function from the R MASS package (Venables and Ripley 2002). This function selects the best model based on the Akaike Information 
Criteria. The relationship between plant survival and predictive variables retained by the different best-fit models were visualized by means of partial regression plots, using the function avPlots from the car package. The relative importance (as percentage) and bootstrap confidence intervals of the explanatory variables retained in the best fit models were assessed by means of the Lindemann-Merenda-Gold (Img) method for calculating sequentially weighted partial $R^{2}$ (Lindeman et al. 1980), using the R "relaimpo" package (Gromping 2006). This method calculates an average coefficient of partial determination for each model permutation using the individual contribution of each explanatory variable.

\section{Results}

\subsection{Inorganic nutrients and $P$. oceanica survival}

The addition of fish fodder to sediments resulted in a significant increase of DIN concentration in the water column above rhizomes $\left(F_{2,51}=10.93 p=0.0001\right.$; Fig. 1$)$; as shown by the SNK tests, the increment in DIN was proportional to the amount of fodder added $(\mathrm{HN}>\mathrm{MN}>\mathrm{AN})$. By contrast, there were no significant differences in DIP among treatments $\left(F_{2,51}=3.08 p=0.0547\right)$.

The comparison between CBAN and PC shows that there was no artefact of PVC cylinders on shoot mortality at both week $3\left(\mathrm{~F}_{1,4}=0.25 \mathrm{p}=0.6430\right)$ and week $11\left(\mathrm{~F}_{1,4}=0.04\right.$ $\mathrm{p}=0.8554$ ) (Fig. 2). P. oceanica shoot survival was significantly affected by sand burial, as about the $25 \%$ of shoots died by week 3 in the HB units (Fig. 2 and Table 2, $H B<M B=C B$ ). Burial was the only stressor affecting mortality of the seagrass in the short-term (3 weeks). After that, shoot survival decreased through time and, after 11 weeks, it was regulated by the interactive effects of nutrient addition and burial (Table 2; Fig. 2). In units exposed to high burial, shoot survival under high and intermediate nutrients addition was lower than at ambient nutrient levels $(\mathrm{HBHN}=\mathrm{HBMN}<\mathrm{HBAN})$. In contrast, shoot survival was not affected 
by nutrients levels in units exposed to either medium or ambient burial (SNK tests in Table 2). At high nutrients levels, shoot survival was lower in units exposed to high than medium or ambient burial levels $(\mathrm{HBHN}<\mathrm{MBHN}=\mathrm{CBHN})$. At medium nutrients levels, the survival decreased with increasing severity of burial ( $\mathrm{HBMN}<\mathrm{MBMN}<\mathrm{CBMN})$, while at ambient nutrient levels, there was no difference among burial treatments (Fig. 2 and Table 2, CBAN=MBAN=HBAN).

Synergistic effects of both high and medium nutrients addition and high burial were further assessed by comparing the average response of $P$. oceanica shoot survival (\%), both at each stressor level and at each combination of stressor levels, with those obtained for the theoretical additive response of stressors levels in combination (Fig. 3). In fact, for the average response given at high nutrient addition (HN), medium nutrient addition (MN), and high burial (HB) when applied individually, the cumulative effects under additive conditions $(\mathrm{HN}+\mathrm{HB}$ and $\mathrm{MN}+\mathrm{HB})$ on shoot survival would have been about two fold higher than that observed (Fig. 3). The difference in shoot survival between the average experimental evidence and the theoretical additive estimates provides evidence for the synergism between nutrient (high and medium) and burial (high) stressors.

\section{2. $P$. oceanica predictive variables}

After three weeks since treatments, nutrient addition changed epiphyte load, necrosis and leaf growth rate, among morphological/growth variables, phenolics and the antioxidant response, ORAC and TEAC, among the physiological variables. However, there was no significant effect of nutrient enrichment on isotopes or gene expression, except for the stress gene HSP90, which experienced a slight inactivation (Fig. 4, 5, 6 and Table 3). In contrast, burial significantly increased epiphyte load and affected gene expression of GADPH, PGK, psbA, CA-chl and ATPa (Table 3). 
The only variables that responded to the interactive effects of nutrient addition and burial were the percentage of leaf necrosis and phenolics content, being one the mirror pattern of the other (Table 3): the first was significantly greater at high nutrient levels when plants were exposed to high burial $(\mathrm{HN}>\mathrm{MN}=\mathrm{AN})$ and at high burial levels if plants were at ambient nutrients levels $(\mathrm{HB}>\mathrm{MB}=\mathrm{CB})$, while the latter was smaller at high nutrients levels condition only when plants were exposed to $\mathrm{HB}(\mathrm{HN}<\mathrm{MN}=\mathrm{AN})$, and in high buried plants only at $\mathrm{HN}(\mathrm{HB}<\mathrm{MB}=\mathrm{CB})$.

The multiple regressions conducted with genetic, isotope, antioxidant and morphological covariates explained the $60.6 \%, 33.2 \%, 36.4 \%$ and $27.8 \%$ (Adjusted $R^{2}$ values) of the variance in shoot survival, respectively (Table 4). After simplification through the step-wise procedure, the best fit model at the level of gene expression included two explanatory variables, CA-chl and ATPa, although only the effects of the former was significant, contributing nearly for $84 \%$ of the variation in shoot mortality explained by the model (Table 5; Fig. 6). The positive estimate of CA-chl suggests that overexpression of this gene at week 3 is positively correlated with shoot survival at week 11 (Fig. S3). CA-chl is directly related with carbon metabolism (correlated to PGK and GADPH) and was, in fact, down-regulated in treatments, such as HBHN and HBMN (SNK test, Table 6), where $P$. oceanica had the lowest survival. ATPa is a gene involved in the photosynthesis (correlated to psbA and psbD) and was up-regulated in high burial treatments (Fig. 6 and Table 6).

Four explanatory variables were retained in the best fit isotope model and only one of these, namely leaf $\delta^{34} \mathrm{~S}$, was significantly related with shoot survival at 11 weeks and accounted for about $50 \%$ of the total variation in shoot survival explained by the model (Table 4). However, although leaf $\delta^{34}$ S was positively (Fig. S4) related with shoot survival, the ANOVA did not identify any significant effect neither of nutrient addition nor of burial on 
leaf $\delta^{34} \mathrm{~S}$ content (Table 3). The best fit antioxidant model retained two variables, ORAC

378 and phenolic content, both of which were significantly correlated with shoot survival. Phenolic contents accounted for a greater proportion ( 63\%) than ORAC ( $37 \%)$ of the total variability in shoot mortality explained by the model (Table 4). Coefficient estimates were negative for ORAC and positive for phenolics (Fig. S5).

\section{DISCUSSION}

\subsection{Synergistic effects of nutrients and burial on $P$. oceanica mortality}

$P$. oceanica shoot survival was affected by synergistic effects of burial and nutrient addition over a short time. High sediment load (HB), corresponding to the complete burial mortality

Over a longer term, burial and nutrient enrichment had interactive, negative effects on $P$. oceanica survival. In particular, high nutrients levels $(\mathrm{HN})$ had the potential to accelerate the regression of the seagrass subjected to high burial. The use of a gradient of both stressors, manipulated in a crossed design, has also allowed detecting the rapid threshold responses to their combinations. Thus, by week 11, HB in combination with either $\mathrm{HN}$ or $\mathrm{MN}$, caused a shoot loss of about $60 \%$. In addition, the slow decrease in 
shoot survival under high burial without organic loading (HBAN), suggests that mortality at $\mathrm{HB}$ was determined by the level of nutrient load, from the fastest at HN to the slowest at AN.

Total shoot mortality did not occur within 11 weeks since the start of the experiment, even under the most stressful conditions and it is unknown whether it would have occurred on a longer term. However, several mechanisms may underpin the survival of some shoots within experimental plots. First, the clonal integration with neighbouring shoots immediately outside the unit edge: continuity between shoots was not prevented to avoid further stress that would have biased the response of the plants. Thus, transfer of metabolites (e.g. carbohydrates) from non-treated plants may have sustained the survival of plants experimentally exposed to stressful conditions. Second, burial effect might have not been homogeneous among shoots within each experimental unit, as rhizome height varied among them and samples were only three-replicated. Third, individual response to stress can differ. Differences in resilience can be related to individual characteristics (e.g. age) of single ramets or to genetic peculiarities of single genets. More resilient genotypes could respond better to the synergistic action of the applied stressors (Hughes and Randall 2004).

\subsection{Predictive variables of $P$. oceanica collapse}

The protraction of the experiment for 11 weeks allowed detecting widespread mortality in experimental units exposed to HBHN and HBMN. Thus, besides the identification of lethal effects of burial and eutrophication on P. oceanica, our study enabled the identification of the plant attributes (morphological/growth, physiological/biochemical and transcriptomic) at week 3 , prior to mortality, related to survival at week 11 


\subsubsection{Morphological/growth variables}

Except for the increase in epiphyte load, changes in morphological variables and growth rate were little effective in predicting seagrass loss (Table 6). An increase in epiphyte biomass, especially macroalgae, is a common response to eutrophic conditions (Piazzi et al. 2016) and the ratio between epiphyte and leaf biomass in P. oceanica is one of the descriptors used to assess the ecological quality of Mediterranean water bodies under the European Water Framework Directive (Gobert et al. 2009, Oliva et al. 2012). Our study shows that the epiphyte load can be used also as an indicator of burial stress, as probably a consequence of lower phenolics content in the buried plants (Costa et al. 2015). Furthermore, signals of imminent mortality can also be gained by the percent of leaves with necrosis; leaf necrosis has been previously suggested to increase with eutrophication (Roca et al. 2016). Here, a higher proportion of leaves exposed to both high burial and both high and medium nutrient addition had necrotic spots which were not uniformly distributed along the blades, being mostly concentrated on the basal part of the leaf. Finally, leaf growth was accelerated by nutrient addition, but was not related to burial, suggesting that this variable is inadequate for predicting imminent seagrass degradation due to the combination of stressors.

\subsubsection{Physiological/biochemical variables}

Based on the multiple regressions, the biochemical/physiological variables associated with the $P$. oceanica survival, were the phenolic content, ORAC and $\delta^{34} S$. Among these, only phenolics are likely to be a useful predictor (positive coefficient), since differences in their concentration were also related to the interactive effect of nutrient addition and burial (Table 6). Phenolics can have multiple biological functions mainly related to the reproductive strategy, adaptation and survival to environmental disturbances, antimicrobial and antifouling properties. Their deposition as lignin in cell 
walls increases their mechanical strength and improves plant response against pathogens and wounding. Variations in phenolics content have been observed in $P$. oceanica as a response to changes in water quality and when competing with invasive species (Pergent et al. 2008, Migliore et al. 2007, Rotini et al. 2013).

Furthermore, ORAC, which reflects the ability of the plant metabolism to scavenge oxygen reactive species (ROS, Mittler, 2002) through hydrogen atom donation (both enzymatically and non-enzymatically), was negatively associated with $P$. oceanica survival, and shoots with higher ORAC will have higher probability of mortality for the high concentrations of ROS. However, it only responded to nutrient addition (Table 6). Furthermore, the $\delta^{34} S$ content (positive coefficient) would suggest that the presence of sulphide intrusion in leaf tissue, lower leaf $\delta^{34} S$ signature, could predict greater shoot survival (Table S4). However, this isotopic signal did not respond uniformly to any treatment, probably due to the sediment type (i.e. coarse-carbonate sediments, Oliva 2012): indeed, the relationship between sediment sulfide and the $\delta^{34} S$ of $P$. oceanica tissues is known to be rather complex being controlled both by the sediment sulfide concentrations and the oxygen status of the plants (Borum et al. 2005). Because of the high variability, the use of $\delta^{34} S$ as an indicator for fish farm effects on $P$. oceanica has already not been supported (Frederiksen et al. 2007). Therefore, among the biochemical/physiological variables only results in leaf phenolics content are promising enough to promote it as an indicator of nutrient and burial stressors of $P$. oceanica (Table $6)$.

\subsubsection{Expression of selected genes}

Gene expression of target genes had the highest correlation with shoot survival. Photosynthetic genes (ATPa, psbD and psbA) were up-regulated in response to high burial suggesting that high sediment load tends to increase the number of PSII and ATP 
synthase, probably to compensate for high energy consumption. By contrast, carbon metabolism genes (CA-chl, PGK and GADPH) were down-regulated, being associated with plant survival. In particular, the experimental treatments significantly affected the ability of plants to fix $\mathrm{C}$ and recycle ATP through glucolysis or gluconeogenesis, as suggested by the significant down-regulation of PGK. This response is likely to result in a long-term starvation of the plants, likely contributing to the high mortality observed in these treatments. In other words, burial produced a strong effect on the carbon metabolism of plants, reducing carbon fixation and the production of energy: buried plants invested energy to increase the amount of PSII and ATP synthase to sustain the thylacoid proton gradient necessary to produce more ATP. Further, because HSP90 is an ATP-dependent molecular chaperone it is possible that a strong ATP reduction experienced by plants from the most intense treatments resulted in lower expression levels of this gene. It is also known that inhibition of HSP90 induced cell death in plants (Nishizawa-Yokoi et al. 2010; Moshe et al. 2016) and, likely, the observed down-regulation is promoting and anticipating plant mortality two months in advance.

\subsection{Conclusions}

This study has estimated that $P$. oceanica shoot survival strongly depends on the interactive effects of levels of intensity of nutrients and burial and it has identified some early changes in plant attributes. Within the whole set of possible predictors of seagrass collapse, only a few were associated with shoot survival (with different contribution to the total variability) and these did not necessarily correspond to those affected by the treatments (Table 6). Furthermore, they were attributed to a different reliability level based on the association to shoot survival. Overall, the evaluation of the candidate indicators of $P$. oceanica regression for the consequences of high organic load and sediment burial has produced some very promising evidence for the gene CA-chl, and secondly of ATPa, while 
500 phenolics and epiphyte load are likely to be less reliable predictors. Thus, the sensitivity of $501 P$. oceanica attributes to these stressors has increased as the level of biological 502 organization decreases (according to expectations, Roca et al. 2016), underlining the 503 importance of implementing monitoring protocols with biochemical and molecular 504 indicators. However, high-replicated studies that include different field conditions (e.g. 505 sediment type, wave exposure) are needed so that consistency of variables' response 506 would be estimated and solid predictors incorporation promoted in any kind of management program (i.e. assessment of ecosystem status, environmental quality, 508 impacts or the results of mitigation actions).

Nevertheless, no morphological change of shoot or leaf size should be expected after 510 a severe storm or flood that accumulates high loads of sediments, rich in organic matter, 511 over a $P$. oceanica bed; these attributes are likely to be reliable warnings only of pressing 512 disturbances over a longer temporal scale (Roca et al. 2016). Consequently, if other levels 513 of biological organization besides the morphological are not considered, the seagrass 514 collapse without early warning signals (Pace et al. 2015). Our results indicate that the 515 interaction between two of the main regional anthropogenic stressors in temperate coastal 516 ecosystems, eutrophication and high sediment loads (the deposition of organic detritus 517 likely brings with it increased sediments, Terrados et al. 1999), can trigger the fast collapse 518 of seagrass meadows without any major phenological change.

In the growing interest of identifying the type and role of interactions among local 520 anthropogenic stressors in driving habitat shifts in marine ecosystems (Russell and 521 Connell 2012), this controlled factorial experiment provides evidence that eutrophication 522 and burial have non-additive consequences on seagrass beds. The input of excess 523 nutrients (primarily nitrate and phosphate) to the marine environment is a global problem 524 associated with a range of human activities, but coastal eutrophication through organic 
matter dispersal represents a further source of disturbance. In fact, the addition of a detrital layer to a seagrass bed will not just result in increased dissolved inorganic nutrients to the sediments, it will have a whole stimulatory impact upon the microbial, fungal and detrital feeding community (Danovaro et al. 1994). A likely additional effect of increased organic detritus is that of increasing the levels of sulphide stress within the sediments with follow-up negative effects upon the seagrass (Marbà et al. 2006). Indirectly, our results provide strong evidence suggesting that development of coastal areas and their associated human activities will have major impacts on the seagrass meadows and such information should be used to identify appropriate local management actions to halt the global loss of seagrasses in favour of alternative habitats composed by either macroalgae or anoxic mud (Unsworth et al. 2015).

Finally, local anthropogenic stressors are thought to negatively interact with global climatic stressors resulting in decline of many habitats, such as coral reefs, macroalgal forests, mangroves and seagrasses. These findings suggest that shifts from seagrass systems to dead rhizomes (i.e. dead matte) in areas characterized by poor water quality, may become more common under future scenarios of climate change (Garcia et al. 2013), as frequency and intensity of storms and floods are expected to increase.

Because our study has demonstrated that the effects of nutrients and sediment burial on seagrasses are synergistic, strategies for reducing nutrient levels, a widely advocated strategy for seagrass conservation, should be pursued bearing in mind the need to control also sedimentation rates. Local management of nutrient loading can represent a valid tool for mitigating the impacts of global stressors on marine macrophytes (Falkenberg et al. 2010). Our study shows that reducing nutrient loading may be not sufficient to enhance the resistance of seagrasses to global stressors, such as seawater warming (NOAA 2016). Given the cumulative nature of human impacts and the large small-scale variation in life- 
550 traits occurring in coastal environments, one size fits all strategies are unlikely be

551 successful for sustaining the functioning of marine ecosystems in the face of climate

552 changes. In addition, our study makes a first step towards the identification of response

553 variables that may function as early warning signals of imminent seagrass collapse. It also

554 provides evidence for increased indicator specificity at lower levels of biological

555 organisation, promoting the need of implementing monitoring with molecular analyses. As

556 a final note of caution, the robustness of the response variables identified as most

557 promising must be assessed against variations in stressor intensity and background

558 abiotic and biotic conditions before their implementation in monitoring programs.

\section{Acknowledgements}

560 Analyses were performed at the Servizos de Apoio á Investigación-Universidade da

561 Coruña (Leaf N, Leaf C, and corresponding isotopic signatures), Iso-Analytical Ltd (Leaf S

562 and leaf $\delta^{34}$ S). We are grateful to Capo Caccia-Isola Piana MPA administration for

563 facilitating the samplings within their domains. This research was supported by MIUR, the

564 Italian Ministry of Education and Research, (TETRIS grant 2011-2015) and by Fondazione

565 di Sardegna (EIMS grant 2016-2019). PG acknowledges the support of S. Porrello and E.

566 Persia at ISPRA laboratories for water nutrient analysis.

567

568 LITERATURE CITED

569 Adams SM, Greeley MS (2000) Ecotoxicological Indicators of Water Quality: Using Multi570 response Indicators to Assess the Health of Aquatic Ecosystems. Water, Air, and Soil $571 \quad$ Pollution 123:103-115. 
Alcoverro T, Romero J, Duarte CM, López NI (1997) Spatial and temporal variations in nutrient limitation of seagrass Posidonia oceanica growth in the NW Mediterranean. Marine Ecology Progress Series 146:155-161.

Andersen CL, Jensen JL, Orntoft TF (2004) Normalization of realtime quantitative reverse transcription-PCR data: a model-based variance estimation approach to identify genes suited for normalization, applied to bladder and colon cancer data sets. Cancer Research 64:5245-5250.

Ashraf M, Harris PJC (2013) Photosynthesis under stressful environments: An overview. Photosynthetica 51 (2):163-190.

Bellwood DR, Hughes TP, Folke C, Nyström M (2004) Confronting the coral reef crisis. Nature 429:827-833.

Boettiger C, Hastings A (2013) From patterns to predictions. Nature 493:157-158.

Bockelmann AC, Beining K, Reusch TBH (2011) Widespread occurrence of endophytic Labyrinthula spp. in northern European eelgrass Zostera marina beds. Marine Ecology Progress Series 445:109-116.

Booker FL, Miller JE (1998) Phenylpropanoid metabolism and phenolic composition of soybean [Glycine max (L.) Merr.] leaves following exposure to ozone. Journal of Experimental Botany 49:1191-1202.

Borum J, Pedersen O, Greve TM, Frankovich TA, Zieman JC, Fourqurean JW, et al. (2005) The potential role of plant oxygen and sulphide dynamics in die-off events of the tropical seagrass, Thalassia testudinum. Journal of Ecology 93:148-158. 
Bulthuis DA (1983) Effects of in situ light reduction on density and growth of the seagrass Heterozostera tasmanica (Martens ex Aschers.) den Hartog in Western Port, Victoria, Australia. Journal of Experimental Marine Biology and Ecology 67:91-103.

Burkholder JM, Tomasko DA, Touchette BW (2007) Seagrasses and eutrophication. Journal of Experimental Marine Biology and Ecology 350:46-72.

Cabaço S, Santos R (2014) Human-induced changes of the seagrass Cymodocea nodosa in Ria Formosa lagoon (Southern Portugal) after a decade. Cahier de Biologie Marine 55:101-108.

Cabaço S, Santos R, Duarte CM (2008) The impact of sediment burial and erosion on seagrasses: a review. Estuarine, Coastal and Shelf Science 79 (3):354-366.

Carpenter J (2011) May the best analyst win. Science 331:698-699.

Costa M, Barrote I, Silva J, Olivé I, Costa MM (2015) Epiphytes modulate Posidonia oceanica photosynthetic production, energetic balance, antioxidant mechanisms and oxidative damage. Frontiers in Marine Science doi.org/10.3389/fmars.2015.00111.

Costanza R, d'Arge R, de Groot R, Farber S, Grasso M, Hannon B, Limburg K, Naeem S, O'Neill RV, Paruelo J, Raskin RG, Sutton P, Van den Belt M (1997) The value of the world's ecosystem services and natural capital. Nature 387:253-260.

Crain CM, Kroeker K, Halpern BS (2008) Interactive and cumulative effects of multiple human stressors in marine systems. Ecology letters 11:1304-1315.

Danovaro R, Fabiano M, Boyer M (1994) Seasonal changes of benthic bacteria in a seagrass bed (Posidonia oceanica) of the Ligurian Sea in relation to origin, composition and fate of the sediment organic matter. Marine Biology 119:489-500. 
615 Dattolo E, Ruocco M, Brunet C, Lorenti M, Lauritano C, Sanges R, De Luca P, Procaccini 616 G (2014) Response of the seagrass Posidonia oceanica to different light 617 environments: insight from a combined molecular and photo-physiological study. 618 Marine Environmental Research 101:225-236.

619 Dattolo E, Marín-Guirao L, Ruiz J, Procaccini G (2017) Long-term acclimation to reciprocal 620 light conditions reveals depth-related selection in the marine foundation species

Delgado O, Ruiz J, Perez M, Romero R, Ballesteros E (1999) Effects of fish farming on seagrass (Posidonia oceanica) in a Mediterranean bay: seagrass decline after organic loading cessation. Oceanologica Acta 22:109-117.

Erftemeijer PLA, Lewis RRR (2006) Environmental impacts of dredging on seagrasses: a review. Marine Pollution Bulletin 52:1553-1572.

Falkenberg LJ, Connell BD, Russel SD (2010) Disrupting the effects of synergies between stressors: improved water quality dampens the effects of future $\mathrm{CO}_{2}$ on a marine habitat. Journal of Applied Ecology 50:51-58.

Fonseca MS, Cahalan JA (1992) A preliminary evaluation of wave attenuation by four species of seagrass. Estuarine, Coast Shelf Science 35:565-576.

Fonseca MS, Koehl MAR (2006) Flow in Seagrass canopies: the influence of patch width. Estuarine, Coastal and Shelf Science 67:1-9.

Fourqurean JW, Robblee MB (1999) Florida Bay: A recent history of ecological changes. Estuaries 22:345-357. 
Frederiksen MS, Holmer M, Diaz-Almela E, Marba N, Duarte CM (2007) Sulfide invasion in the seagrass Posidonia oceanica at Mediterranean fish farms: assessment using stable sulphur isotopes. Marine Ecology Progress Series 345:93-104.

Garcì-Sanz T, Ruiz-Fernandez JM, Ruiz M, Garcia R, Gonzalez MN, Perez M (2010) An evaluation of a macroalgal bioassay tool for assessing the spatial extent of nutrient release from offshore fish farms. Marine Environmental Research 70:189-200.

Garcia R, Holmer M, Duarte CM, Marbà N (2013) Global warming enhances sulphide stress in a key seagrass species (NW Mediterranean). Global Change Biology 19:3629-3639.

Gera A, Pagès JF, Arthur R, Farina S, Roca G, Romero J, Alcoverro T (2014) The effect of a centenary storm on the long-lived seagrass Posidonia oceanica. Limnology and Oceanography 59:1910-1918.

Giakoumi S, Halpern BS, Michel LN, Gobert S, Sini M, Boudouresque CF, Gambi MC, Katsanevakis S, Lejeune P, Montefalcone M, Pergent G, Pergent-Martini C, SanchezJerez P, Velimirov B, Vizzini S, Abadie A, Coll M, Guidetti P, Micheli F, Possingham HP (2015) Towards a framework for assessment and management of cumulative human impacts on marine food webs. Conservation Biology 29(4):1228-1234.

Gobert S, Sartoretto S, Rico-Raimondino V, Andral B, Chery A, Lejeune P, Boissery P (2009) Assessment of the ecological status of Mediterranean French coastal waters as required by the Water Framework Directive using the Posidonia oceanica Rapid Easy Index, PREI. Marine Pollution Bulletin 58:1727-1733.

Govers LL, de Brouwer JHF, Suykerbuyk W, Bouma TJ, Lamersc LPM, Smolders AJP, van Katwijk MM (2014) Toxic effects of increased sediment nutrient and organic matter loading on the seagrass Zostera noltii. Aquatic toxicology 155:253-260. 
Griffen BD, Belgrad BA, Cannizzo ZJ, Knotts ER, Hancock ER (2016) Rethinking our approach to multiple stressor studies in marine environments. Marine Ecology Progress Series 543:273-281.

Gromping U (2006) Relative importance for linear regression in R: The package relaimpo, Journal of Statistical Software 17(1):1-27.

Heck KL, Hays C, Orth RJ (2003) A critical evaluation of the nursery role hypothesis for seagrass meadows. Marine Ecology Progress Series 253:123-136.

Hemminga MA, Duarte CM (2000) Seagrass ecology. Cambridge University Press

Holmer M, Argyrou M, Dalsgaard T, Danovaro R, Diaz-Almela E, Duarte CM, Frederiksen M, Grau A, Karakassis I, Marbà N, Mirto S, Pérez M, Pusceddu A, Tsapakis M (2008) Effects of fish farm waste on Posidonia oceanica meadows: synthesis and provision of monitoring and management tools. Marine Pollution Bulletin 56:1618-1629.

Huang D, Ou B, Hampsch-Woodill M, Flanagan JA, Prior RL (2002) High-throughput assay of oxygen radical absorbance capacity (ORAC) using a multichannel liquid handling system coupled with a microplate fluorescence reader in 96-well format. Journal of Agricultural and Food Chemistry 50:4437-4444.

Hughes AR, Stachowicz JJ (2004) Genetic diversity enhances the resistance of a seagrass ecosystem to disturbance. Proceedings of the National Academy of Sciences 101:8998-9002.

Larkum AWD, Orth RJ, Duarte CM, (2006) Seagrasses: Biology, Ecology and Conservation. Dordrecht (The Netherlands). Springer. 
Lauritano C, Ruocco M, Dattolo E, Buia MC, Silva J, Santos R, Olivé I, Costa MM, Procaccini G (2015) Response of key stress-related genes of the seagrass Posidonia oceanica in the vicinity of submarine volcanic vents. Biogeosciences 12:4185-4194.

Lindeman RH, Merenda PF, Gold RZ (1980) Introduction to bivariate and multivariate analysis, Scott, Foresman, Glenview, III.

Macreadie PI, Baird ME, Trevathan-Tackett SM, Larkum AWD, Ralph PJ (2014) Quantifying and modelling the carbon sequestration capacity of seagrass meadows a critical assessment. Marine Pollution Bulletin 83:430-439.

Manzanera M, Alcoverro T, Tomas F, Romero J (2011) Response of Posidonia oceanica to burial dynamics. Marine Ecology Progress Series 423:47-56.

Marbà N, Duarte CM, Díaz-Almela E, Terrados J, Álvarez E, Martínez R, Santiago R, Gacia E, Grau AM (2005) Direct evidence of imbalanced seagrass (Posidonia oceanica) shoot population dynamics along the Spanish Mediterranean. Estuaries 28:53-62.

Marbá N, Santiago R, Díaz-Almela E, Álverez E, Duarte CM (2006) Seagrass (Posidonia oceanica) vertical growth as an early indicator of fish farm-derived stress. Estuarine, Coastal and Shelf Science 67:475-483.

Marín-Guirao L, Ruiz JM, Dattolo E, Garcia-Munoz R, Procaccini G (2016) Physiological and molecular evidence of differential short-term heat tolerance in Mediterranean seagrasses. Scientific Reports 6:28615.

Mazzuca S, Bjork M, Beer S, Felisberto P, Gobert S, Procaccini G, Runcie J, Silva J, Borges AV, Brunet C, Buapet P, Champenois W, Costa MM, D'Esposito D, Gullstrom M, Lejeune P, Lepoint G, Olive I, Rasmusson M, Richir J, Ruocco M, Serra IA, 
Spadafora A, Santos R (2013) Establishing research strategies, methodologies and technologies to link genomics and proteomics to seagrass productivity, community metabolism, and ecosystem carbon fluxes. Frontiers in Plant Science 4:38.

McMahon K, Collier C, Lavery PS (2013) Identifying robust bioindicators of light stress in seagrasses: A meta-analysis. Ecological Indicators 30:7-15.

Migliore L, Rotini A, Randazzo D, Albanese NN, Giallongo A (2007) Phenols content and 2-D electrophoresis protein pattern: a promising tool to monitor Posidonia meadows health state. BMC Ecology 7:6.

Mittler R (2002) Oxidative stress, antioxidants and stress tolerance. Trends in Plant Science 7:405-410.

Montefalcone M (2009) Ecosystem health assessment using the Mediterranean sea- grass Posidonia oceanica: a review. Ecological Indicators 9:595-604.

Moshe A, Gorovits R, Liu Y, Czosnek H (2016) Tomato plant cell death induced by inhibition of HSP90 is alleviated by Tomato yellow leaf curl virus infection. Molecular Plant Pathology 17:247-260.

Munkes B (2005) Eutrophication, phase shift, the delay and the potential return in the Greifswalder Bodden, Baltic Sea. Aquatic Sciences 67:372-381.

Nishizawa-Yokoi A, Tainaka H, Yoshida E, Tamoi M, Yabuta Y, Shigeoka S (2010) The 26S Proteasome function and Hsp90 activity involved in the regulation of HsfA2 expression in Response to oxidative stress. Plant and Cell Physiology 51:486-496.

NOAA (National Oceanic and Atmospheric Administration) (2016) Extended reconstructed sea surface temperature (ERSST.v4). National Centers for Environmental Information. Accessed March 2016. www.ncdc.noaa.gov/data-access/marineocean-data/extendedreconstructed-sea-surface-temperature-ersst. 
Oliva S (2012) Seagrass systems under human pressure: responses and assessment tools. PhD Thesis Universitat de Barcelona (Spain).

Oliva S, Mascaró O, Llagostera I, Pérez M, Romero J (2012) Selection of metrics based on the seagrass Cymodocea nodosa and development of a biotic index (CYMOX) for assessing ecological status of coastal and transitional waters. Estuarine, Coastal and Shelf Science 114:7-17.

Orth RJ, Moore KA (1983) Chesapeake Bay: an unprecedented decline in submerged aquatic vegetation. Science 222:51-53.

Orth RJ, Carruthers TJB, Dennison WC, Duarte CM, Fourqurean JW, Heck KLjr, Hughes AR, Kendrick GA, Kenworthy WJ, Olyarnik S, Short FT, Waycott M, Williams SL (2006) A Global Crisis for Seagrass Ecosystems. Bioscience 56:987-996.

Pace ML, Carpenter SR, Cole JJ (2015) With and without warning: managing ecosystems in a changing world. Frontiers in Ecology and the Environment 13:460-467.

Pergent G, Boudouresque CF, Dumay O, Pergent-Martini C, Wyllie-Echeverria S (2008) Competition between the invasive macrophyte Caulerpa taxifolia and the seagrass Posidonia oceanica: contrasting strategies. BMC Ecology 8:20.

Perry CT, Morgan KM (2017) Bleaching drives collapse in reef carbonate budgets and reef growth potential on southern Maldives reefs. Scientific Reports 7:40581 DOI: $10.1038 /$ srep40581

Piazzi L, Balata D, Ceccherelli G (2016) Epiphyte assemblages of the Mediterranean seagrass Posidonia oceanica: an overview. Marine Ecology 37:3-41.

Prado P, Alcoverro T, Romero J (2008) Seasonal response of Posidonia oceanica epiphyte assemblages to nutrient increase. Marine Ecology Progress Series 359:8998. 
Re R, Pellegrini N, Proteggente A, Pannala A, Yang M, Rice-Evans C (1999) Antioxidant activity applying an improved ABTS radical cation decolorization assay. Free Radical Biology and Medicine 26:1231-1237.

Roca G, Alcoverro T, Krause-Jensen D, Balsby TJS, van Katwijk MM, Marbà N, Santos R, Arthur R, Mascaró O, Fernández-Torquemada Y, Pérez M, Duarte CM, Romero J (2016) Response of seagrass indicators to shifts in environmental stressors: a global review and management synthesis. Ecological Indicators 63:310-323.

Rotini A, Belmonte A, Barrote I, Micheli C, Peirano A, Santos RO, Silva J, Migliore L (2013) Effectiveness and consistency of a suite of descriptors to assess the ecological status of seagrass meadows (Posidonia oceanica L. Delile). Estuarine, Coastal and Shelf Science 130:252-259.

Ruíz JM, Pérez M, Romero J (2001) Effects of fish farm loadings on seagrass (Posidonia oceanica) distribution, growth and photosynthesis. Marine Pollution Bulletin 42(9):749760.

Russell BD, Connell SD (2012) Origins and consequences of global and local stressors: incorporating climatic and non-climatic phenomena that buffer or accelerate ecological change. Marine Biology 159(11):2633-2639.

Serra IA, Lauritano C, Dattolo E, Puoti A, Nicastro S, Innocenti AM, Procaccini G (2012) Reference genes assessment for the seagrass Posidonia oceanica in different salinity, $\mathrm{pH}$ and light conditions. Marine Biology 159:1269-1282.

Short FT, Wyllie-Echeverria S (1996) Natural and human-induced disturbance of seagrasses. Environmental Conservation 23:17-27. 
Tamburello L, Benedetti-Cecchi L, Ghedini G, Bulleri F (2012) Variation in the structure of subtidal landscapes in the NW Mediterranean Sea. Marine Ecology Progress Series 457:29-41.

Telesca L, Belluscio A, Criscoli A, Ardizzone G, Apostolaki ET, Fraschetti S, Gristina M, Knittweis L, Martin CS, Pergent G, Alagna A, Badalamenti F, Garofalo G, Gerakaris V, Pace ML, Pergent-Martini C, Salomidi M (2015) Seagrass meadows (Posidonia oceanica) distribution and trajectories of change. Scientific Reports 5:12505.

Terrados J, Duarte CM, Kamp-Nielsen L, Agawin NSR, Gacia E, Lacap D, Fortes MD, Borum J, Lubanski M, Greve T (1999) Are seagrass growth and survival affected by reducing conditions in the sediment? Aquatic Botany 65:175-197.

Underwood AJ (1997) Experiments in ecology: their logical design and interpretation using analysis of variance. Cambridge University Press

Unsworth RKF, Collier CJ, Waycott M, McKenzie LJ, Cullen-Unsworth LC (2015) A framework for the resilience of seagrass ecosystems. Marine Pollution Bulletin 100:3446.

Unsworth RKF, Cullen LC, Pretty JN, Smith DJ, Bell JJ (2010) Economic and subsistence values of the standing stocks of sea- grass fisheries: potential benefits of no-fishing marine protected area management. Ocean and Coastal Management 53:218-224.

Unsworth RKF, Collier CJ, Waycott M, Mckenzie LJ, Cullen-Unsworth LC (2015) A framework for the resilience of seagrass ecosystems. Marine Pollution Bulletin 100:3446. 
Vandesompele J, De Preter K, Pattyn F, Poppe B, Van Roy N, De Paepe A, Speleman F (2002) Accurate normalization of real-time quantitative RT-PCR data by geometric averaging of multiple internal control genes. Genome Biology 3:0034.1.

Van Katwijk MM, Van der Welle MEW, Lucassen ECHET, Vonk JA, Christianen MJA, Kiswara W, Inayat al Hakim I, Arifin A, Bouma TJ, Roelofs JGM, Lamerset LPM (2011) Early warning indicators for river nutrient and sediment loads in tropical seagrass beds: a benchmark from a near-pristine archipelago in Indonesia. Marine Pollution Bulletin 62:1512-1520.

Venables WN, Ripley BD (2002) Modern Applied Statistics with S. Fourth Edition. Springer, New York.

Walker DI, Kendrick GA, McComb AJ (2006) Decline and recovery of seagrass ecosystems-the dynamics of change. Pages 551-565 in Larkum, A.W.D., Orth, R.J. and Duarte, C.M., eds. Seagrasses: Biology, Ecology and Conservation. Dordrecht (The Netherlands): Springer.

Waycott M, Duarte CM, Carruthers TJB, Orth RJ, Dennison WC, Olyarnik S, Calladine A, Fourqurean JW, Heck KL, Hughes AR, Kendrick GA, Kenworthy WJ, Short FT, Williams SL (2009) Accelerating loss of seagrasses across the globe threatens coastal ecosystems. Proceedings of the National Academy of Sciences 106:12377-12381.

Whitham TG, Bailey JK, Schweitzer JA, Shuster SM, Bangert RK, LeRoy CJ, Lonsdorf EV, Allan GJ, DiFazio SP, Potts BM, Fischer DG, Gehring CA, Lindroth RL, Marks JC, Hart SC, Wimp GM, Wooley SC (2006) A framework for community and ecosystem genetics: from genes to ecosystems. Nature Reviews Genetics 7:510-523.

Williams SL (2007) Introduced species in seagrass ecosystems: status and concerns. Journal of Experimental Marine Biology and Ecology 350:89-110. 
819 Zuur AF, leno EN, Elphick CS (2010) A protocol for data exploration to avoid common 820 statistical problems. Methods in Ecology and Evolution 1:3-14. 
Table 1. The $P$. oceanica response variables classified in the three levels of biological organization.

\begin{tabular}{|c|c|c|c|}
\hline Morphological/growth & & $\begin{array}{l}\text { Physiological and } \\
\text { biochemical }\end{array}$ & $\begin{array}{c}\text { Gene } \\
\text { expression }\end{array}$ \\
\hline $\begin{array}{l}\text { Epiphyte load }(\mathrm{mg} / \mathrm{sh}) \\
\text { Necrosis }(\% \text { leaf) } \\
\text { Max leaf length }(\mathrm{cm}) \\
\text { Mean leaf length }(\mathrm{cm}) \\
\text { Num of leaves/shoot } \\
\text { Shoot biomass }(\mathrm{g} \mathrm{DW}) \\
\text { Leaf growth rate }(\mathrm{cm} / \text { sh.day) }\end{array}$ & 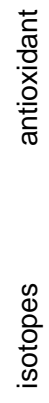 & $\begin{array}{l}\text { ORAC }(\mu \mathrm{mol} \text { EQT/g DW) } \\
\text { TEAC }(\mu \mathrm{mol} / \mathrm{g} \mathrm{DW}) \\
\text { Phenolics }(\mathrm{mg} / \mathrm{g} \mathrm{DW}) \\
\text { Leaf } \mathrm{N}(\%) \\
\text { Leaf } \delta^{15} \mathrm{~N}(\%) \\
\text { Leaf } \mathrm{C}(\%) \\
\text { Leaf } \delta^{13} \mathrm{C}(\%) \\
\text { Leaf } \mathrm{S}(\%) \\
\text { Leaf } \delta^{34} \mathrm{~S}(\%)\end{array}$ & $\begin{array}{l}\text { GADPH } \\
\text { SHSP } \\
\text { HSP90 } \\
\text { PGK } \\
\text { CAB-151 } \\
\text { psbD } \\
\text { psbA } \\
\text { CA-chl } \\
\text { rbcl } \\
\text { ATPa }\end{array}$ \\
\hline
\end{tabular}


Table 2. ANOVAs on the effects of Nutrients (three levels: high, medium, and ambient; HN, MN, AN), and Burial (three levels: high, medium, and none; HB, MB, CB) on shoot survival after 3 and 11 weeks after the start of the experiment. $n=3$. SNK tests results are reported below.

\begin{tabular}{|c|c|c|c|c|c|c|c|}
\hline \multirow[b]{2}{*}{ Source } & \multirow[b]{2}{*}{ df } & \multicolumn{3}{|c|}{$\begin{array}{c}\text { shoot survival } \\
3 \text { weeks }\end{array}$} & \multicolumn{3}{|c|}{$\begin{array}{c}\text { shoot survival } \\
11 \text { weeks }\end{array}$} \\
\hline & & MS & $\mathbf{F}$ & $\mathbf{P}$ & MS & $\mathbf{F}$ & $\mathbf{P}$ \\
\hline Nutrients $=(\mathrm{N})$ & 2 & 168.8 & 0.90 & 0.4240 & 631.1 & 7.6 & 0.0041 \\
\hline Burial $=(\mathrm{Bu})$ & 2 & 1181.9 & 6.30 & 0.0084 & 4430.8 & 53.3 & 0.0000 \\
\hline $\mathrm{N} \times \mathrm{Bu}$ & 4 & 278.1 & 1.48 & 0.2488 & 836.5 & 10.1 & 0.0002 \\
\hline \multirow[t]{3}{*}{ Residual } & 18 & 187.5 & & & 83.1 & & \\
\hline & & \multicolumn{3}{|c|}{$\mathrm{C}=0.3185(\mathrm{~ns})$} & \multicolumn{3}{|c|}{$\mathrm{C}=0.3214(\mathrm{~ns})$} \\
\hline & & \multicolumn{3}{|c|}{ Transform: None } & \multicolumn{3}{|c|}{ Transform: None } \\
\hline \multirow[t]{6}{*}{ SNK test } & & \multicolumn{3}{|c|}{$\begin{array}{c}\mathrm{Bu}, \mathrm{SE}=4.561 \\
\mathrm{HB}<\mathrm{MB}=\mathrm{CB}\end{array}$} & \multicolumn{3}{|c|}{$\begin{array}{l}\mathrm{N} \times \mathrm{Bu}, \mathrm{SE}=5.263 \\
\mathrm{HB}: \mathrm{HN}=\mathrm{MN}<\mathrm{AN}\end{array}$} \\
\hline & & & & & \multicolumn{3}{|c|}{ MB: $\mathrm{HN}=\mathrm{MN}=\mathrm{AN}$} \\
\hline & & & & & \multicolumn{3}{|c|}{$\mathrm{CB}: \mathrm{HN}=\mathrm{MN}=\mathrm{AN}$} \\
\hline & & & & & \multicolumn{3}{|c|}{$\mathrm{HN}: \mathrm{HB}<\mathrm{MB}=\mathrm{CB}$} \\
\hline & & & & & \multicolumn{3}{|c|}{$\mathrm{MN}: \mathrm{HB}<\mathrm{MB}<\mathrm{CB}$} \\
\hline & & & & & \multicolumn{3}{|c|}{$\mathrm{AN}: \mathrm{HB}=\mathrm{MB}=\mathrm{CB}$} \\
\hline
\end{tabular}


Table 3. ANOVAs on the effects of Nutrient addition (three levels: high, medium, and ambient; $\mathrm{HN}, \mathrm{MN}, \mathrm{AN}$ ) and Burial (three levels: high, medium, and none; $\mathrm{HB}, \mathrm{MB}, \mathrm{CB}$ ) on morphological/growth, physiological/biochemical and gene expression response variables. Significant $F$ values are reported in bold; ${ }^{*}=\mathrm{p}<0.05$

\begin{tabular}{|c|c|c|c|}
\hline Variable & $\begin{array}{c}\text { Nutrients } \\
F_{2,18}\end{array}$ & $\begin{array}{c}\text { Burial } \\
F_{2,18}\end{array}$ & $\begin{array}{c}\text { Nutrients } \times \text { Burial } \\
F_{4,18}\end{array}$ \\
\hline $\begin{array}{l}\text { Morphological/growth } \\
\text { Epiphyte load } \\
\text { Necrosis } \\
\text { Max leaf length } \\
\text { Mean leaf length } \\
\text { Num of leaves/shoot } \\
\text { Shoot biomass } \\
\text { Leaf growth rate }\end{array}$ & $\begin{array}{c}\mathbf{6 . 2 3} \text { * } \\
\mathbf{5 . 8 3} \text { * } \\
1.48 \\
1.58 \\
1.06 \\
0.48 \\
\mathbf{3 . 9 0} \text { * }\end{array}$ & $\begin{array}{l}4.10 \text { * } \\
2.91 \\
2.60 \\
2.41 \\
0.72 \\
0.89 \\
0.39 \\
\end{array}$ & $\begin{array}{c}2.76 \\
3.06 \text { * } \\
1.33 \\
1.45 \\
0.22 \\
2.07 \\
2.14 \\
\end{array}$ \\
\hline $\begin{array}{l}\text { Physiological and } \\
\text { biochemical } \\
\text { ORAC } \\
\text { TEAC } \\
\text { Phenolics }\end{array}$ & $\begin{array}{c}5.01 \text { * } \\
5.11 \text { * } \\
0.34\end{array}$ & $\begin{array}{l}3.11 \\
0.26 \\
3.29\end{array}$ & $\begin{array}{c}2.84 \\
2.11 \\
4.07 \text { * }\end{array}$ \\
\hline $\begin{array}{l}\text { Leaf } \mathrm{N} \\
\text { Leaf } \delta^{15} \mathrm{~N} \\
\text { Leaf } \mathrm{C} \\
\text { Leaf } \delta^{13} \mathrm{C} \\
\text { Leaf } \mathrm{S} \\
\text { Leaf } \delta^{34} \mathrm{~S}\end{array}$ & $\begin{array}{l}0.53 \\
0.46 \\
0.74 \\
2.64 \\
3.44 \\
2.91 \\
\end{array}$ & $\begin{array}{l}0.05 \\
1.68 \\
0.86 \\
0.32 \\
0.16 \\
2.66 \\
\end{array}$ & $\begin{array}{l}1.70 \\
2.28 \\
1.31 \\
0.63 \\
0.99 \\
0.20 \\
\end{array}$ \\
\hline $\begin{array}{l}\text { Gene expression } \\
\text { GADPH } \\
\text { SHSP } \\
\text { HSP90 } \\
\text { PGK } \\
\text { CAB-151 } \\
\text { psbD } \\
\text { psbA } \\
\text { CA-chl } \\
\text { rbcl } \\
\text { ATPa }\end{array}$ & $\begin{array}{c}1.04 \\
3.29 \\
\mathbf{4 . 0 6} \\
2.39 \\
0.45 \\
0.19 \\
0.37 \\
2.25 \\
0.10 \\
0.95\end{array}$ & $\begin{array}{c}\mathbf{4 . 2 1} \text { * } \\
0.89 \\
0.26 \\
\mathbf{8 . 0 0} \text { * } \\
1.60 \\
2.52 \\
\mathbf{4 . 5 8} \text { * } \\
\mathbf{9 . 2 5} \text { * } \\
0.67 \\
\mathbf{5 . 7 5} \text { * }\end{array}$ & $\begin{array}{l}1.17 \\
2.47 \\
0.75 \\
2.19 \\
1.31 \\
2.87 \\
2.44 \\
2.03 \\
1.45 \\
2.88\end{array}$ \\
\hline
\end{tabular}


Table 4. Multiple regressions of $P$. oceanica shoot survival against different groups of response variables. Coefficient estimates (Estimate), standard errors (SE), tvalues, and significance level ( $P$-value) for variables retained in the best-fit model are reported.

\begin{tabular}{lcccc}
\hline \multicolumn{1}{c}{ Morphological/growth } & & & & \\
\hline effect & Estimate & SE & t-value & $\boldsymbol{P}$-value \\
\hline Epiphyte load & -0.00365 & 0.00104 & -3.50 & $\mathbf{0 . 0 0 1 9 3}$ \\
Shoot biomass & -0.17576 & 0.10531 & -1.66 & 0.10869 \\
Leaf growth & 0.06651 & 0.03766 & 1.766 & 0.09066
\end{tabular}

Adjusted $\mathrm{R}^{2}=0.2779$

$\mathrm{F}_{3,23}=4.33 \mathrm{P}$-value 0.0146

Physiological and biochemical

(antioxidant)

\begin{tabular}{lrrrr}
\hline effect & Estimate & SE & t-value & $\boldsymbol{P}$-value \\
\hline ORAC & -0.0004 & 0.00013 & -3.045 & $\mathbf{0 . 0 0 5 5 7}$ \\
Phenolics & 0.0007 & 0.00021 & 3.697 & $\mathbf{0 . 0 0 1 1 3}$
\end{tabular}

Adjusted $\mathrm{R}^{2}=0.3644$

$F_{2,24=8.45 P \text {-value } 0.0016}$

Physiological and biochemical

(isotopes)

\begin{tabular}{lccrc}
\hline effect & Estimate & SE & t-value & $P$-value \\
\hline Leaf $\mathrm{N}$ & -0.4591 & 0.2735 & -1.678 & 0.1075 \\
Leaf $\delta^{15} \mathrm{~N}$ & -0.1782 & 0.1195 & -1.491 & 0.1501 \\
Leaf $\mathrm{S}$ & -0.5854 & 0.4482 & -1.306 & 0.2050 \\
Leaf $\delta^{34} \mathrm{~S}$ & 0.0627 & 0.0266 & 2.356 & $\mathbf{0 . 0 2 7 8}$
\end{tabular}

Adjusted $\mathrm{R}^{2}=0.3321$

$F_{2,22}=4.23 P$-value 0.0108

\begin{tabular}{lrrrr} 
Gene expression & & & & \\
\hline effect & Estimate & \multicolumn{1}{c}{ SE } & t-value & P-value \\
\hline CA-chl & 0.0546 & 0.00972 & 5.623 & $\mathbf{0 . 0 0 0 0 0}$ \\
ATPa & -0.0216 & 0.01205 & -1.796 & 0.08510
\end{tabular}


Table 5. Rank of variables contributing most to the $P$. oceanica shoot survival (\% contribution to $\mathrm{R}^{2}$ ).

\begin{tabular}{|c|c|c|c|c|}
\hline \multirow[b]{2}{*}{ Morphological/growth } & \multicolumn{4}{|c|}{$\%$ contribution } \\
\hline & $\begin{array}{c}\text { Epiphyte } \\
\text { load } \\
76.7 \\
\end{array}$ & $\begin{array}{c}\text { Leaf } \\
\text { growth } \\
12.6 \\
\end{array}$ & $\begin{array}{c}\text { Shoot } \\
\text { biomass } \\
10.7\end{array}$ & \\
\hline $\begin{array}{l}\text { Physiological and biochemical } \\
\text { (antioxidant) }\end{array}$ & $\begin{array}{l}\text { Phenolics } \\
63.0\end{array}$ & $\begin{array}{c}\text { ORAC } \\
37.0\end{array}$ & & \\
\hline $\begin{array}{l}\text { Physiological and biochemical } \\
\text { (isotopes) }\end{array}$ & $\begin{array}{l}\delta^{34} S \\
49.5\end{array}$ & $\begin{array}{c}\text { Leaf S } \\
19.2\end{array}$ & $\begin{array}{l}\delta^{15} \mathrm{~N} \\
16.9 \\
\end{array}$ & $\begin{array}{l}\text { Leaf } \mathbf{N} \\
14.4 \\
\end{array}$ \\
\hline Gene expression & $\begin{array}{c}\text { CA-chl } \\
83.8\end{array}$ & $\begin{array}{c}\text { ATPa } \\
16.1\end{array}$ & & \\
\hline
\end{tabular}


Table 6. List of variables evaluated as possible indicators of imminent collapse of $P$. oceanica due to Nutrient $(=\mathrm{N})$ and Burial $(=\mathrm{B})$ stressors. For each of the variables included in the study are reported the direction of stressor effects ( $\uparrow$ =increase and $\boldsymbol{\downarrow}=$ decrease effect and 'no $\mathrm{Ha}$ ' = no alternative hypothesis detected by the SNK tests), the sign and strength of their association with $P$. oceanica shoot survival on the basis of their relative contribution to the total variability explained by the best-fit model (arbitrary scale: $0-25 \%$ : low; $25-50 \%$ : medium; $50-75 \%$ : high; $75-100 \%$ : very high) and reliability based on the total variability explained by the regression model the variables belongs to (arbitrary scale: poor $R^{2}<40$, good $60>R^{2}>40$, very good $R^{2}>60$ ).

\begin{tabular}{|c|c|c|c|}
\hline Variable & $\begin{array}{c}\text { Stressor } \\
\text { effect }\end{array}$ & $\begin{array}{l}\text { Association } \\
\text { to survival }\end{array}$ & $\begin{array}{l}\text { indicator } \\
\text { reliability }\end{array}$ \\
\hline $\begin{array}{l}\text { Epiphyte load } \\
\text { Necrosis } \\
\text { Leaf growth rate }\end{array}$ & 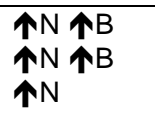 & $\begin{array}{c}\text { very high } \\
- \\
\text { low }\end{array}$ & 응 \\
\hline $\begin{array}{l}\text { ORAC } \\
\text { TEAC } \\
\text { Phenolics }\end{array}$ & $\begin{array}{l}\text { no } \mathrm{Ha} \\
\boldsymbol{\uparrow}_{N}^{N} \\
\downarrow_{N} \downarrow_{B}\end{array}$ & $\begin{array}{c}\text { medium } \\
- \\
\text { high }\end{array}$ & 음 \\
\hline Leaf $\delta^{34} S$ & no effect & medium & 음 \\
\hline GADPH & no $\mathrm{Ha}$ & - & \\
\hline HSP90 & no $\mathrm{Ha}$ & - & \\
\hline PGK & $\downarrow_{\mathrm{B}}$ & very high & 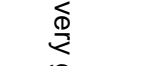 \\
\hline psbA & no $\mathrm{Ha}$ & low & 응 \\
\hline CA-chl & $\downarrow \mathrm{B}$ & & \\
\hline ATPa & $\uparrow B$ & & \\
\hline
\end{tabular}




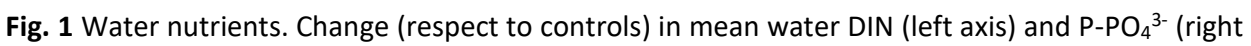
axis) due to experimental nutrient addition. Dots are averages of two sampling times $(n=6)$. Black, grey, and light grey colours indicate high, medium, and control burial (HB, $M B, C B$, respectively). Nutrient addition levels are separated by dashed lines

Fig. 2 P. oceanica shoot survival. Effect of experimental treatments (nutrient addition and burial) after $3,7,9$ and 11 weeks (mean $\pm S E, n=3$ ). Black, grey, and light grey colours denote high, medium, and control burial treatments, respectively $(\mathrm{HB}, \mathrm{MB}, \mathrm{CB}$, respectively). $\mathrm{PC}$ corresponds to Procedural controls

Fig. $3 P$. oceanica survival. Average $(n=3)$ shoot change in controls (CBAN), in each level of each single stressor $(\mathrm{MB}, \mathrm{HB}, \mathrm{MN}$ and $\mathrm{HN}$ ), and in each combination of levels for multiple stressors interactions (MBMN, MBHN, HBMN, and $\mathrm{HBHN}$ ). Grey and striped bars represent the experimental data and the theoretical additive response (calculated by summing the response to the single stressor levels), respectively

Fig. 4 Morphological/growth variables (mean+SE, $n=9)$ change due to nutrient addition ( $H=$ high, $\mathrm{M}=$ medium and $\mathrm{A}=\mathrm{ambient}$ ) and burial (high, medium, and control)

Fig. 5 Physiological/biochemical variables (mean+SE, $n=9$ ) change due to nutrient addition ( $\mathrm{H}=$ high, $\mathrm{M}=$ medium and $\mathrm{A}=$ ambient) and burial (high, medium, and control)

Fig. 6 Stress-related gene expression (mean+SE, $n=9$ ) change due to nutrient addition ( $H=$ high, $\mathrm{M}=$ medium and $\mathrm{A}=\mathrm{ambient}$ ) and burial (high, medium, and control) 


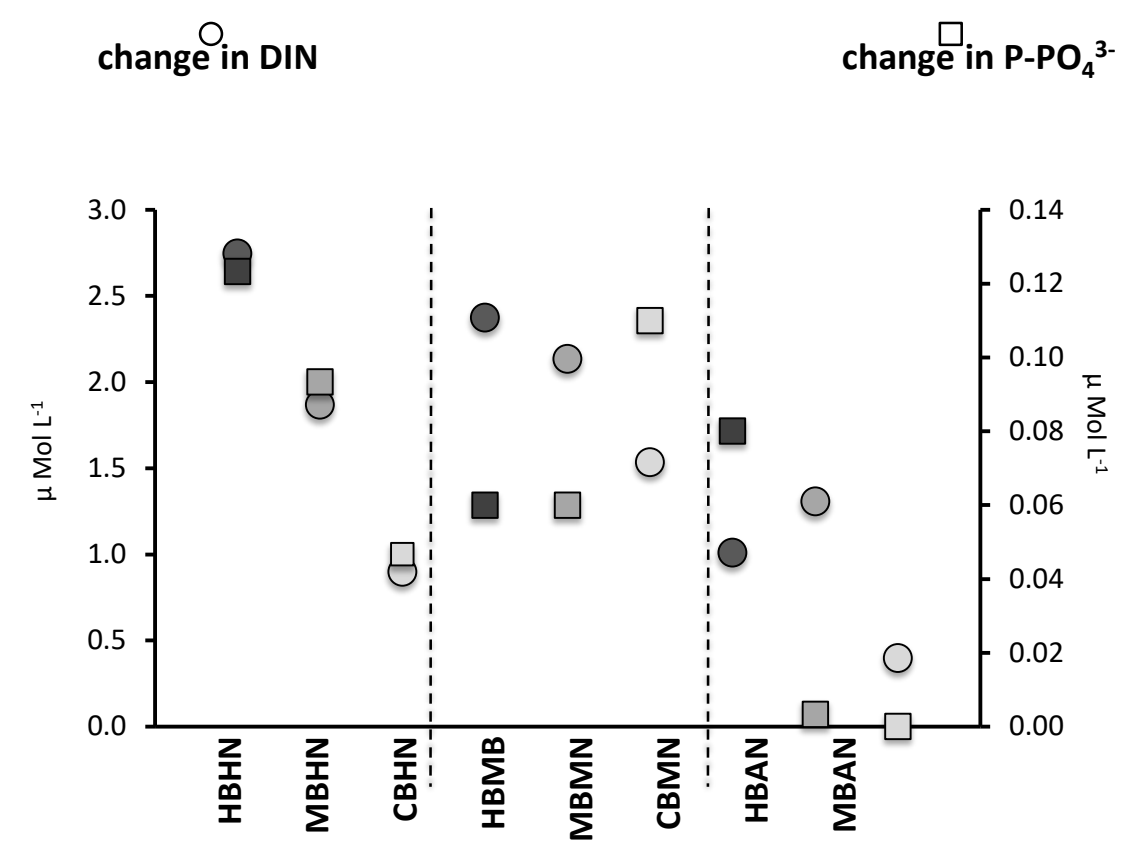

Fig 1 

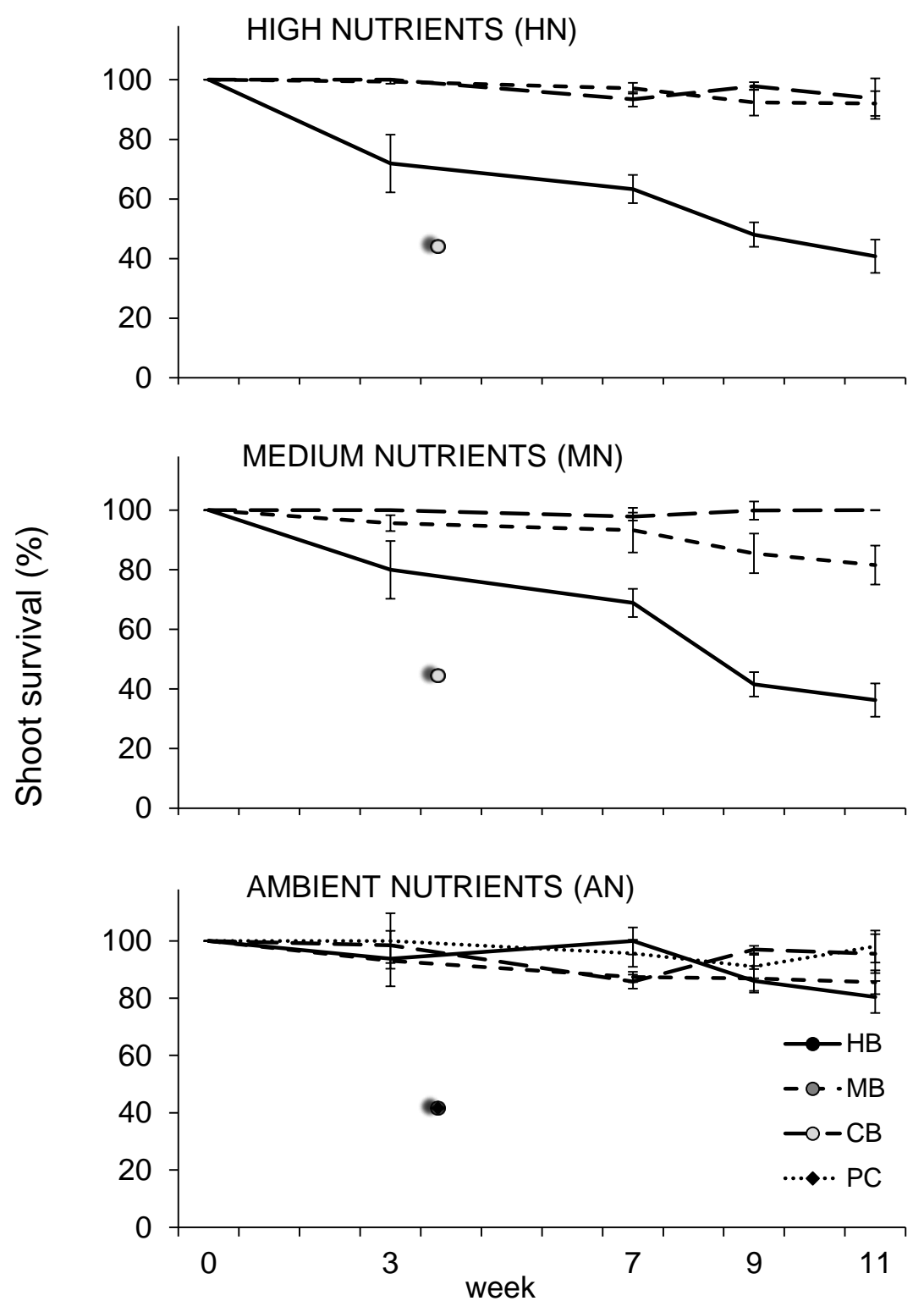

Fig 2 


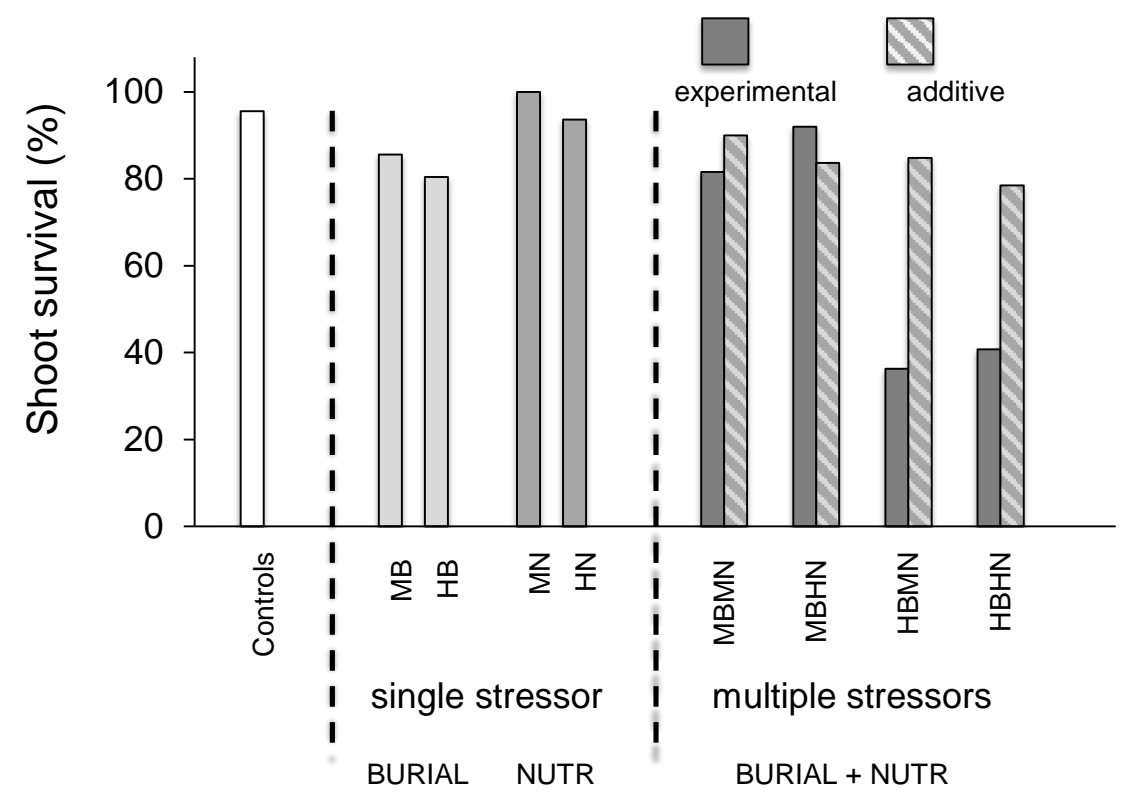

Fig 3 

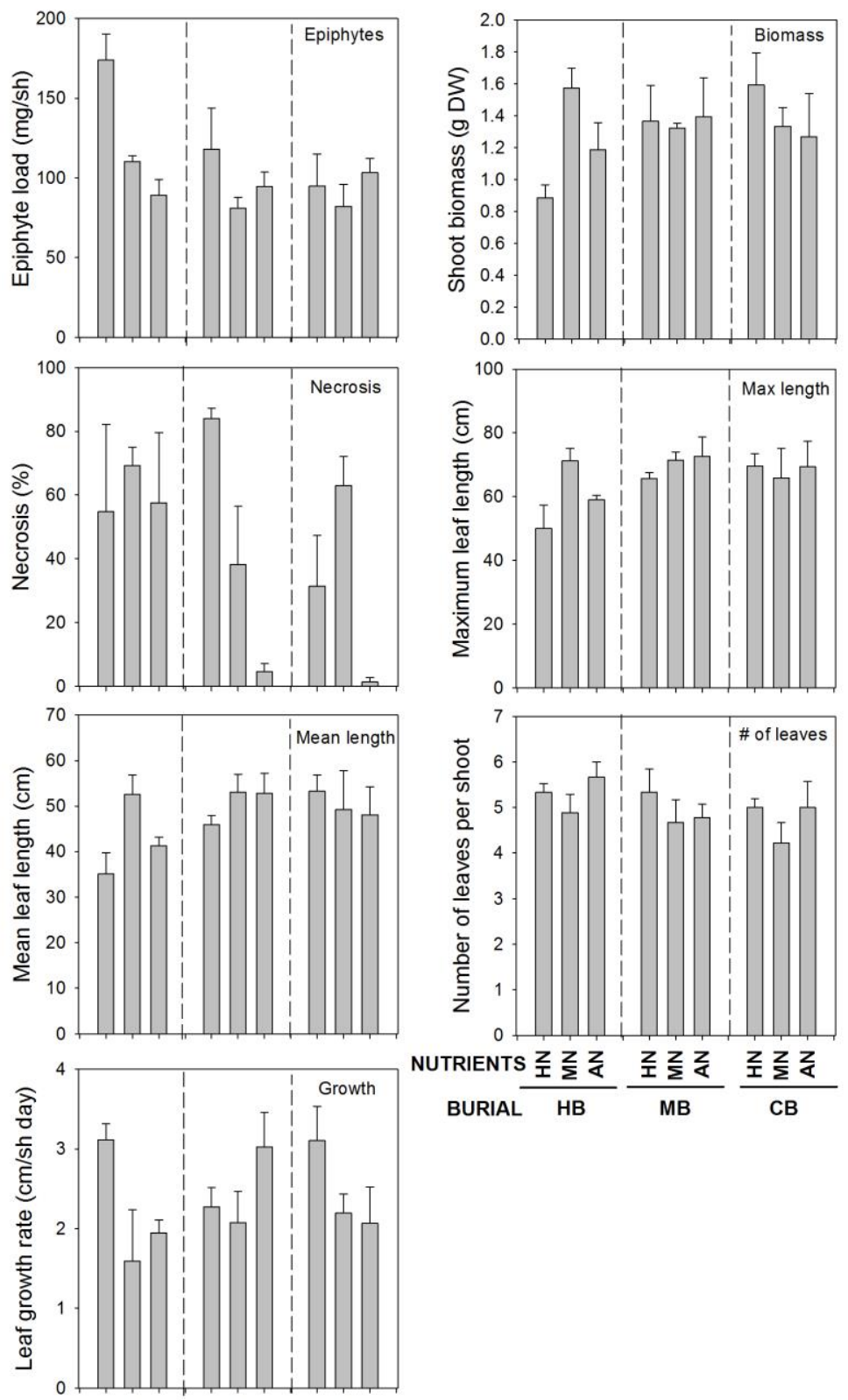

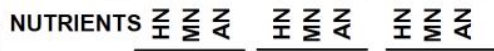

BURIAL HB

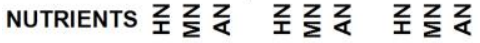

BURIAL HB 

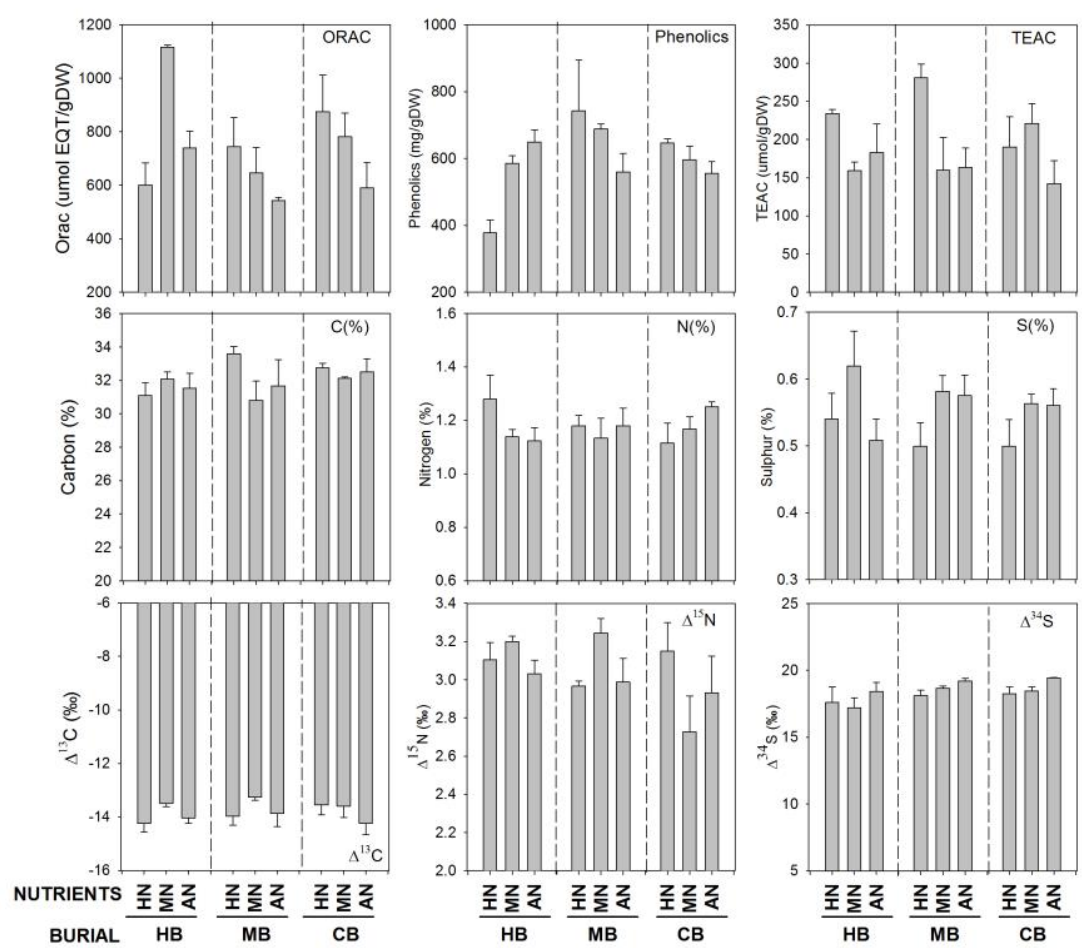

Fig 5 

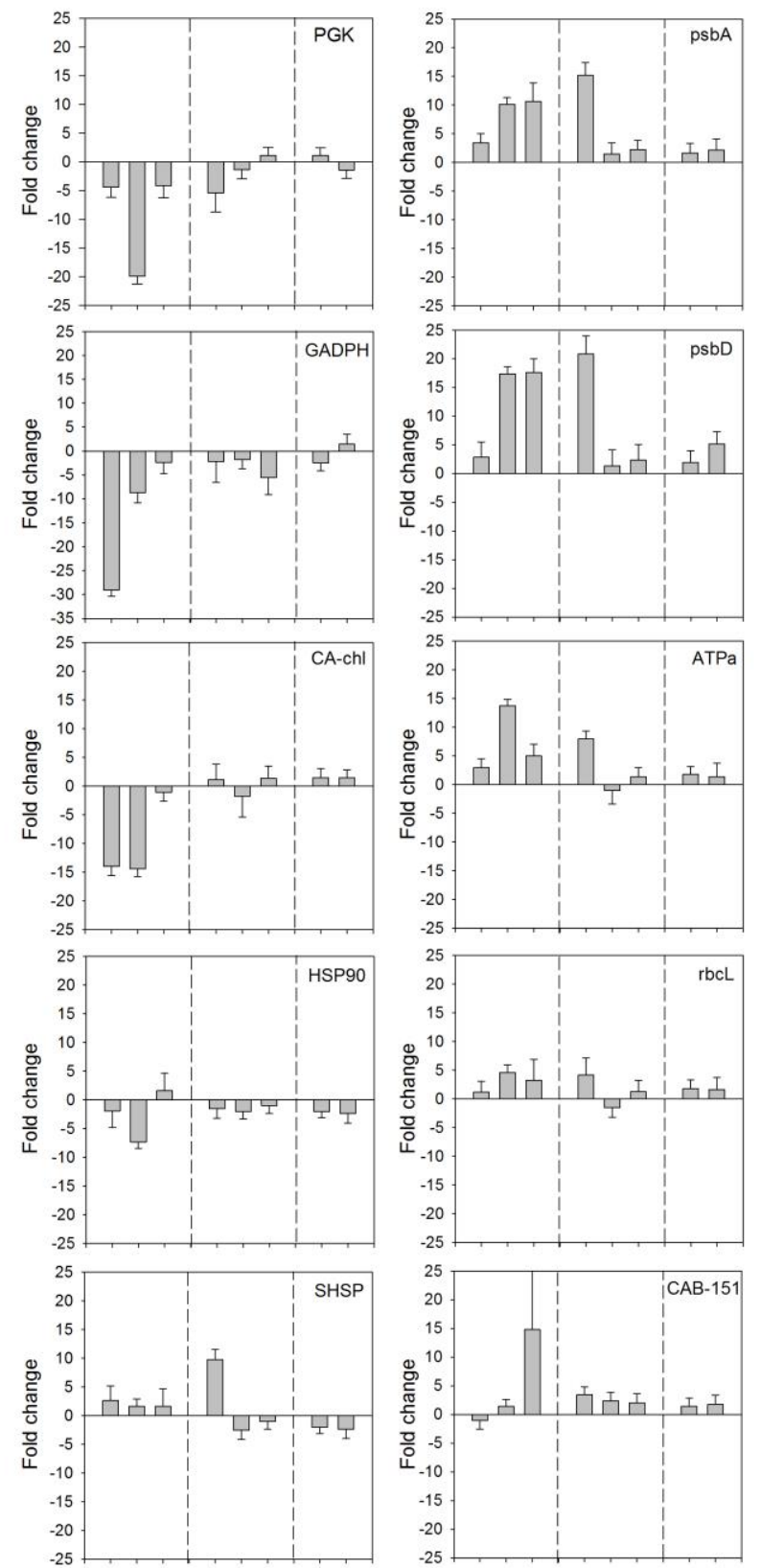

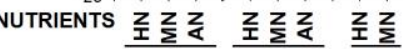

BURIAL $\frac{2}{H B} \frac{x}{M B} \frac{\Sigma}{C B}$

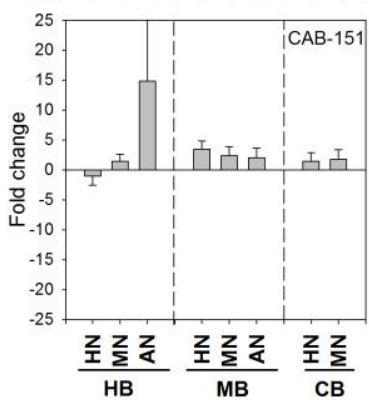

Fig 6 


\section{Seagrass collapse due to synergistic stressors is not anticipated by phenological changes}

Giulia Ceccherelli, Silvia Oliva, Stefania Pinna, Luigi Piazzi, Gabriele Procaccini, Lazaro Marin-Guirao, Emanuela Dattolo, Roberto Gallia, Gabriella La Manna, Paola Gennaro, Monya M. Costa, Isabel Barrote, João Silva, Fabio Bulleri

\section{Supplementary material}

Table S1. List of genes analysed. Sequence of primers and stability curves are reported in the reference in which the genes have been selected for the first time. T: target genes; R: reference genes.

\begin{tabular}{|c|c|c|c|}
\hline Gene name & Symbol & References & Type \\
\hline Photosystem II protein D1 & PSbA & Dattolo et al. 2014 & $\mathrm{~T}$ \\
\hline Photosystem II protein D2 & PSbD & Dattolo et al. 2014 & $\mathrm{~T}$ \\
\hline ATP synthase subunit alpha & ATPa & Marín-Guirao et al. 2016 & $\mathrm{~T}$ \\
\hline Chlorophyll a-b binding protein 151 & CAB-151 & Dattolo et al. 2014 & $\mathrm{~T}$ \\
\hline Phosphoglycerate kinase & PGK & Dattolo et al. 2017 & $\mathrm{~T}$ \\
\hline Carbonic anhydrase, chloroplastic & CA-chl & Dattolo et al. 2017 & $\mathrm{~T}$ \\
\hline Glyceraldehyde-3-phosphate dehydrogenase & GADPH & Serra et al. 2012 & $\mathrm{~T}$ \\
\hline Rubisco large subunit & $\mathrm{rbcL}$ & Marín-Guirao et al. 2016 & $\mathrm{~T}$ \\
\hline Heat Shock Protein 90 & HSP9O & Lauritano et al. 2015 & $\mathrm{~T}$ \\
\hline Small Heat Shock Protein & SHSP & Lauritano et al. 2015 & $\mathrm{~T}$ \\
\hline $18 \mathrm{~S}$ ribosomal RNA & $18 \mathrm{~S}$ & Serra et al. 2012 & $\mathrm{R}$ \\
\hline Elongation factor 1 alpha & EF1A & Serra et al. 2012 & $\mathrm{R}$ \\
\hline Ribosomal protein L23 & L23 & Serra et al. 2012 & $\mathrm{R}$ \\
\hline
\end{tabular}




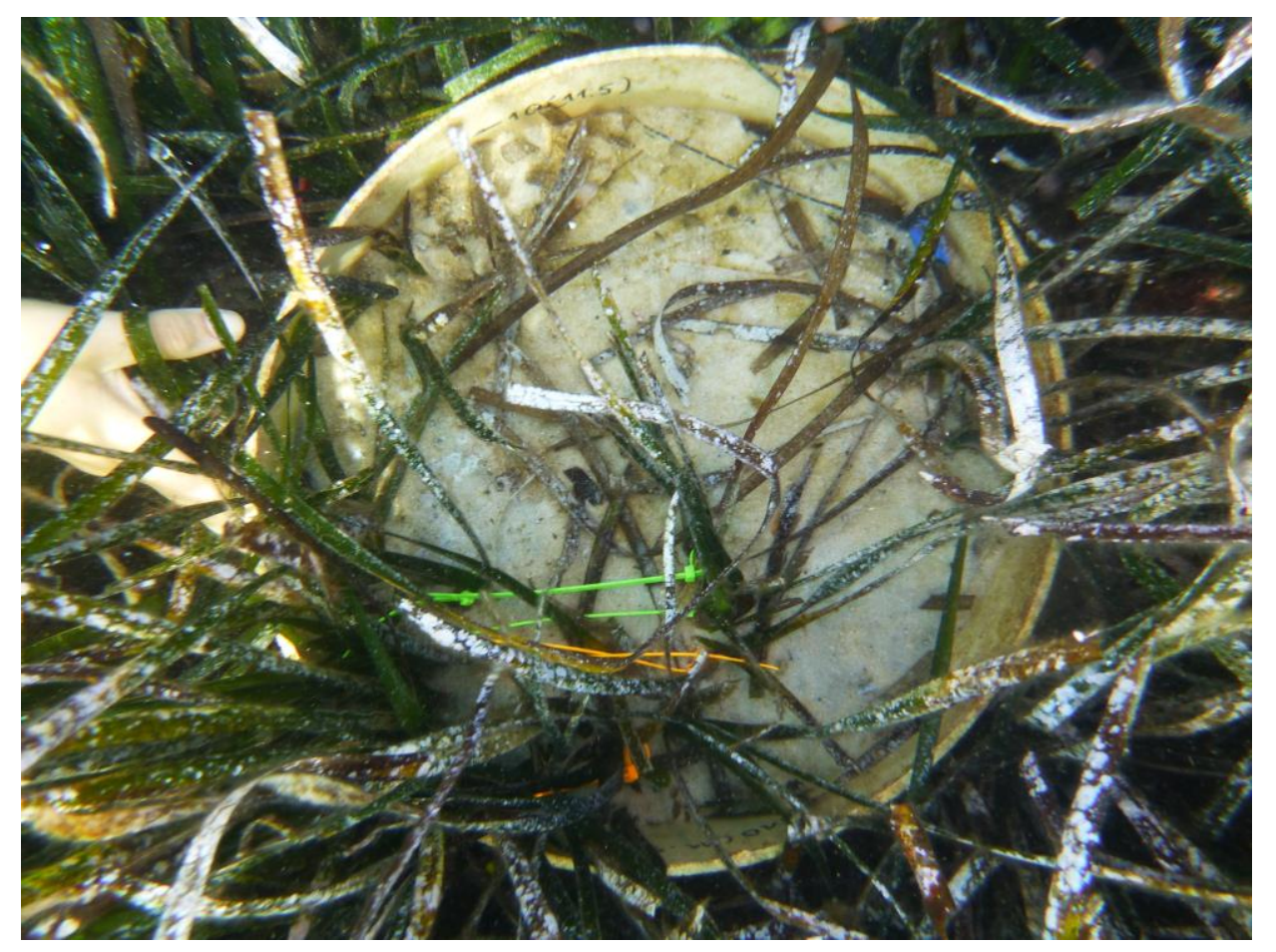

Fig. S1 PVC cylinder bordering an HBHN experimental unit. The coloured cable ties indicate shoots punched for leaf growth rate estimates. 


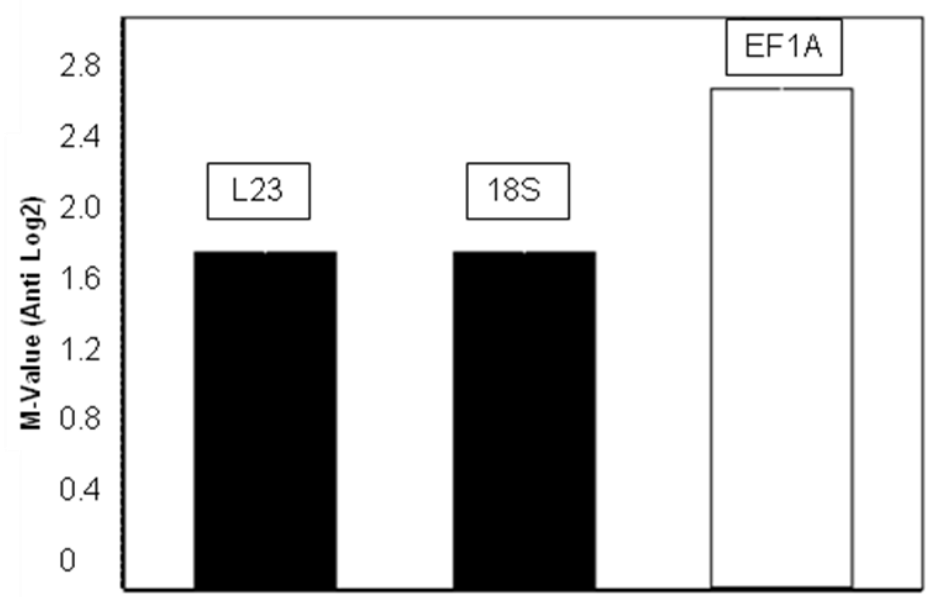

Genes

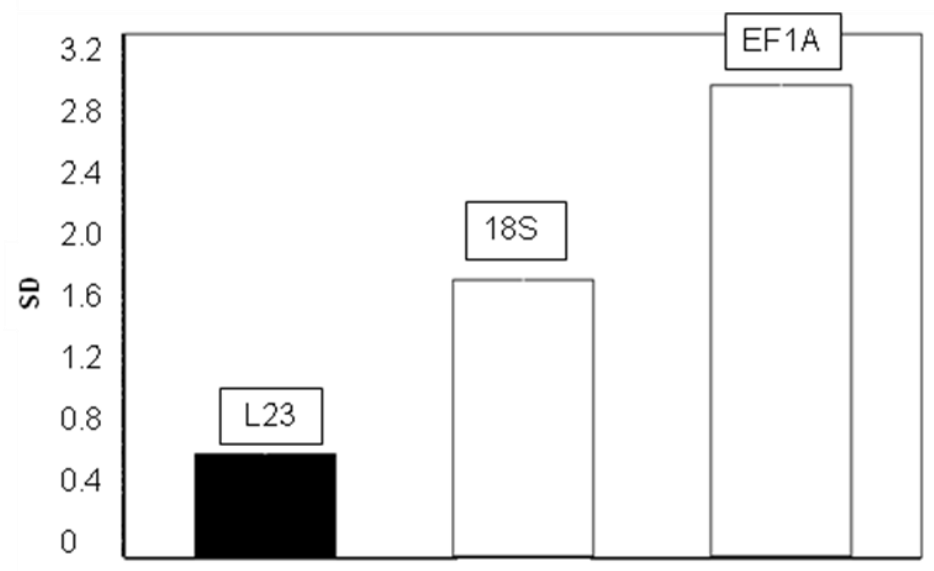

Genes

Fig. S2 Reference genes. Assessment of the stability of three putative reference genes. More stable genes are the ones in black, according to the software geNorm (top panel) and NormFinder (bottom panel). Both L23 and $18 \mathrm{~S}$ have been utilized as reference genes in the analysis. 

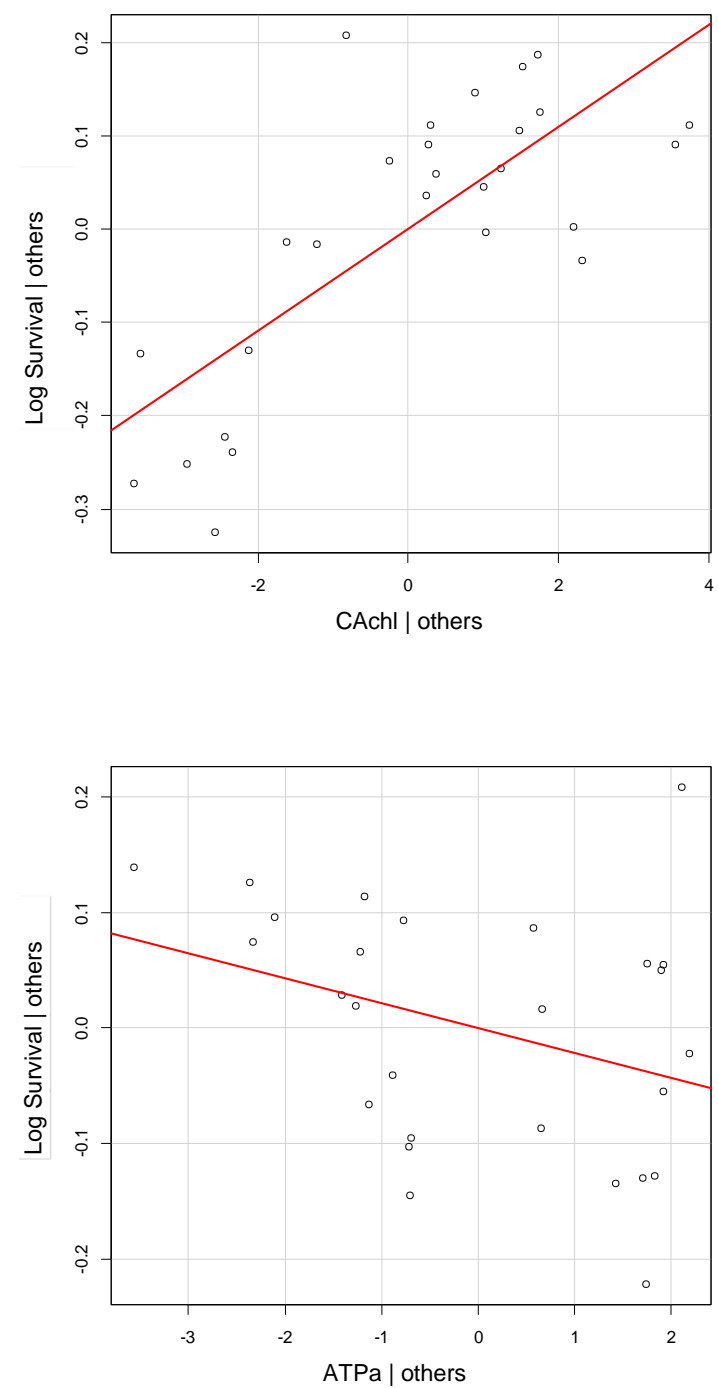

Fig. S3 Partial regression plots for each of the variables retained by the best-fit multiple regression model at the level of gene expression. 

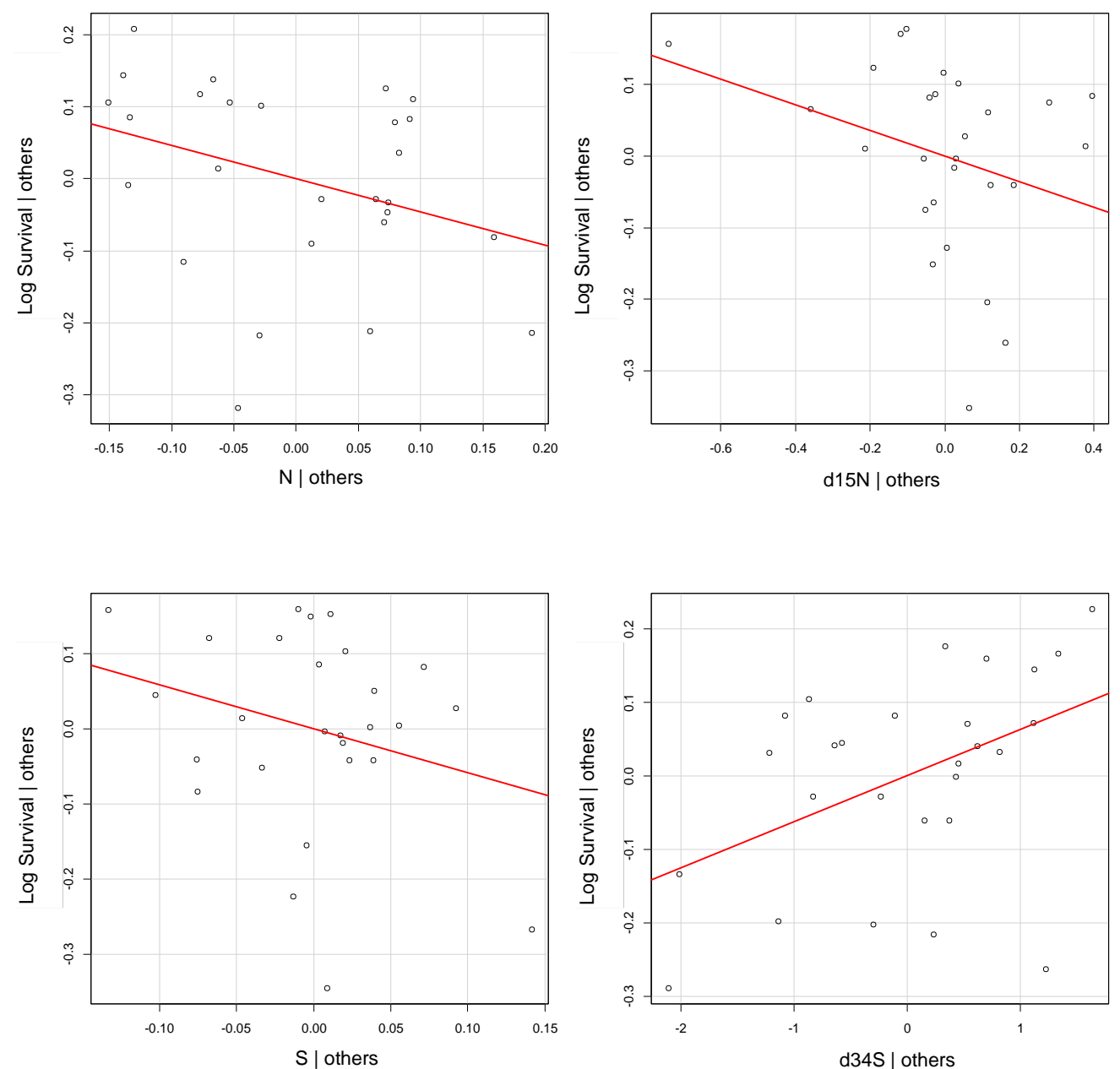

Fig. S4 Partial regression plots for each of the variables retained by the best-fit multiple regression model at the level of isotopes. 

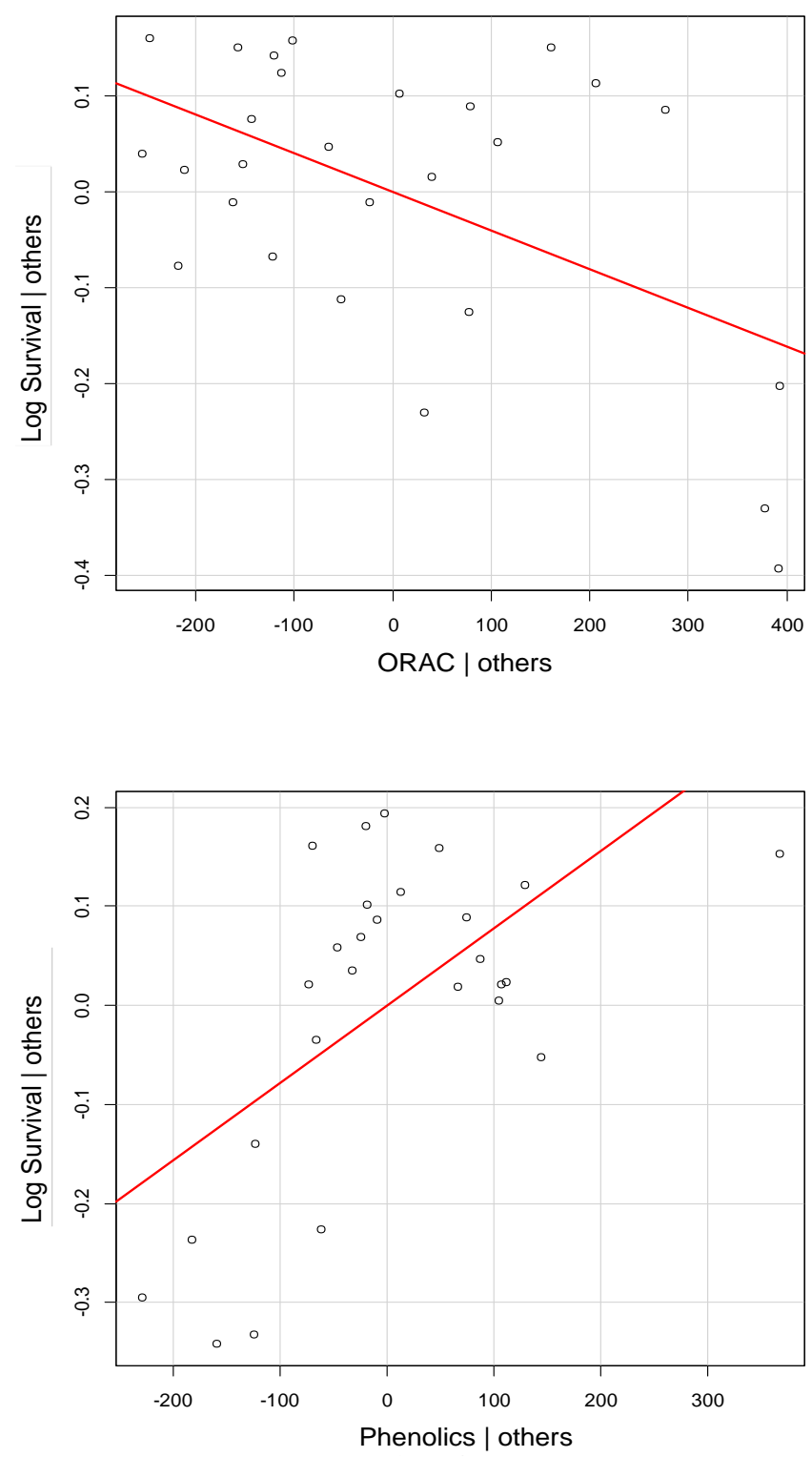

Fig. S5 Partial regression plots for each of the variables retained by the best-fit multiple regression model at the level of antioxidant. 

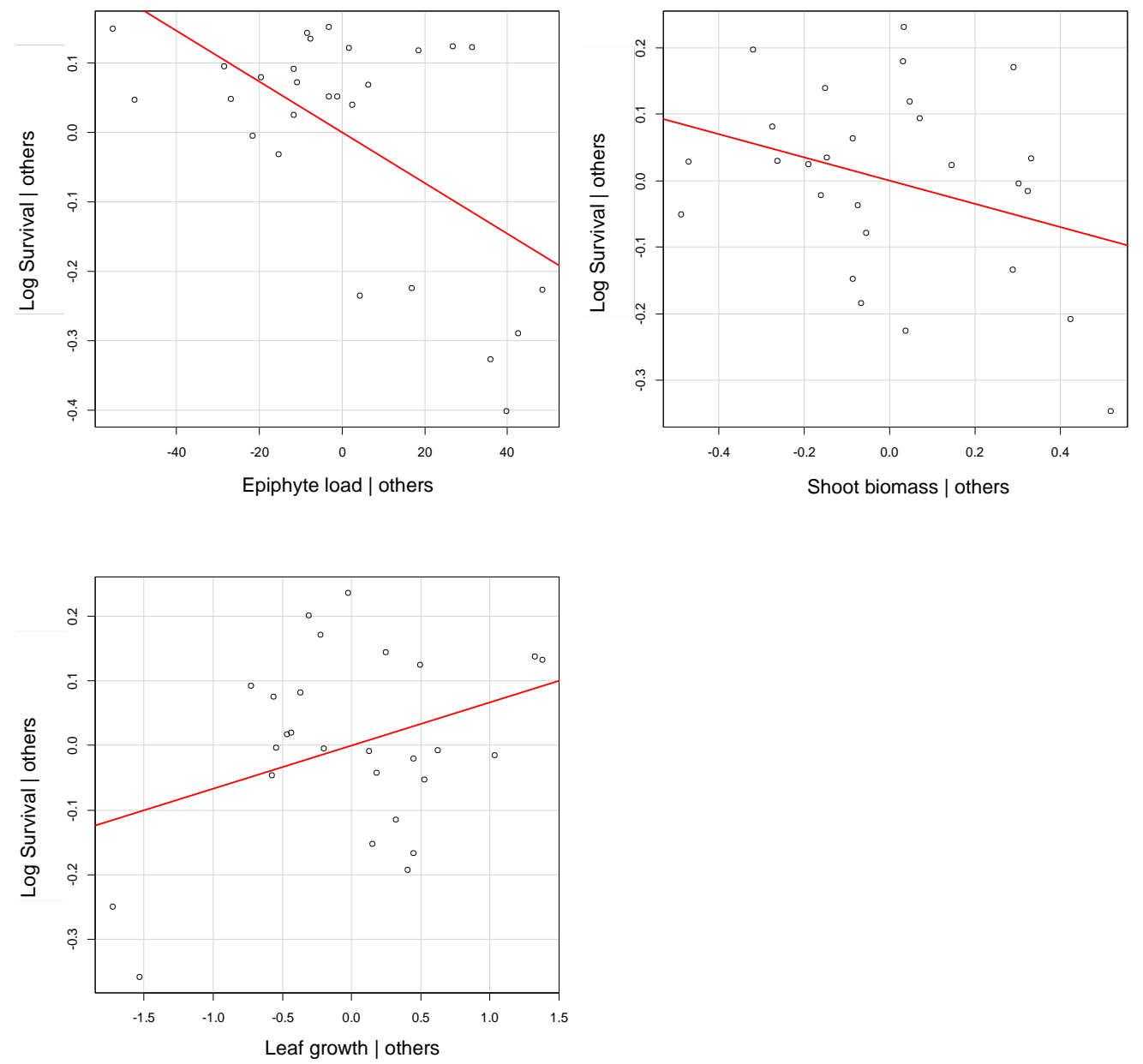

Fig. S6 Partial regression plots for each of the variables retained by the best-fit multiple regression model at the level of plant morphology/growth. 